\title{
Comparative Corporate Criminal Liability: Exploring the Uniquely American Doctrine Through Comparative Criminal Procedure
}

\begin{abstract}
A B STRACT. In the United States, corporations - as entities - can be criminally tried and convicted for crimes committed by individual directors, managers, and even low-level employees. From a comparative perspective, such corporate liability marks the United States as relatively unique. Few other Western countries impose entity liability, and those that do impose such liability comparatively infrequently and under the threat of far less serious punishment. The question of why the United States - and the United States virtually alone-imposes corporate criminal liability has been the subject of limited scholarly attention. This Note seeks to fill that void through the prism of comparative law. Using Germany-a country that imposes no corporate criminal liability - as a foil, this Note argues that the American doctrine can best be explained not through criminal theory but rather through criminal procedure. American criminal procedure imposes unique difficulties on American investigators and prosecutors seeking to root out individual white-collar criminals. But it also imparts powers to those prosecutors that are unknown to their German counterparts. Among them is the power to threaten criminal indictment, one that allows prosecutors to force American corporations to cooperate, to waive the attorney-client privilege, and to cut ties to individual employees under investigation, thereby facilitating the prosecution of those individual defendants. Using differences in criminal procedure rather than criminal theory to explain the uniquely American doctrine, this Note concludes by suggesting how the criminal procedure approach can best be used to understandand potentially to reform - an American system that critics increasingly decry as broken.
\end{abstract}

A UTHOR. Yale Law School, J.D. 2008; Yale College, B.A. 2003. The author wishes to thank Professor James Whitman for inspiring this project and providing extensive feedback on prior drafts; Professors Kate Stith and Steven Duke for their invaluable guidance on this and other projects; and Greg Diskant, Paul Hughes, Richard Re, and Nicolas Thompson for their very helpful comments on the topic and prior drafts. 


\section{NOTE CONTENTS}

$\begin{array}{lr}\text { INTRODUCTION } & 128\end{array}$

I. COMPARATIVE CORPORATE CRIMINAL LIABILITY 134

A. The United States 134

B. Germany 142

C. Comparison $\quad 144$

1. The Criminal Theorist's Account $\quad 144$

2. The Functionalist Account 146

3. Enron "couldn't happen here" 147

4. The "European Efficiency" Account 149

$\begin{array}{ll}\text { D. Summary } & 150\end{array}$

II. THE COMPARATIVE CRIMINAL PROCEDURE ACCOUNT 150

A. The Evidentiary Differences $\quad \cdot 152$

B. Prosecutorial Powers $\quad 159$

C. Finishing the Explanation: How the American System Works in Practice 165

1. The Thompson Memorandum and the Use of "Deferred Prosecution Agreements"

166

2. The American Outcome and Its Surprising Similarity to the German Outcome 


\section{INTRODUCTION}

In post-Enron America, corporations are under attack. Increasing regulation and oversight, the threat of derivative shareholder suits, and the prospect of personal liability for corporate directors have created an atmosphere of constant risk for corporations, one decried by an increasingly vocal band of corporate leaders, legal scholars, ${ }^{1}$ and practitioners. ${ }^{2}$ At the core of that criticism, however, is the area of arguably greatest risk to corporations in modern America: criminal prosecution. In the United States, corporations as entities - can be criminally tried and convicted for crimes committed by individual directors, managers, and even low-level employees. The risk of indictment alone is devastating: a criminal indictment promises a swift market response, the ouster of leadership, millions of dollars in legal fees, and, of course, the possibility of conviction. Such a conviction would lead not only to any criminal penalties imposed (usually a heavy fine), but also to what others have termed "collateral consequences" - devastating financial and reputational repercussions that can, and do, force companies out of business. ${ }^{3}$ As a result, it is common wisdom within the business community that a conviction amounts to a potentially lethal blow for a corporation, ${ }^{4}$ one from which the corporation

1. See, e.g., Lisa Kern Griffin, Compelled Cooperation and the New Corporate Criminal Procedure, 82 N.Y.U. L. REV. 311 (2007); Vikramaditya S. Khanna, Corporate Crime Legislation: A Political Economy Analysis, 82 WASH. U. L.Q. 95 (2004); Dale A. Oesterle, Early Observations on the Prosecutions of the Business Scandals of 2002-03: On Sideshow Prosecutions, Spitzer's Clash with Donaldson over Turf, the Choice of Civil or Criminal Actions, and the Tough Tactic of Coerced Cooperation, 1 OHIO ST. J. CRIM. L. 443 (2004); Thomas C. Pearson \& Gideon Mark, Investigations, Inspections, and Audits in the Post-SOX Environment, 86 NEB. L. REV. 43 (2007).

2. See, e.g., Gregory L. Diskant, Time To Rethink Corporate Criminal Liability, N.Y. L.J., Aug. 2, 2007, at 2; Richard S. Gruner, Three Painful Lessons: Corporate Experience with Deferred Prosecution Agreements, in Advanced Corporate Complance Workshop 51 (Practising Law Inst. ed., 2007); Joan McPhee, The Survival Dilemma, NAT'L L.J., Jan. 21, 2008, at 4; Mark Robeck, Amy Vasquez \& Michael E. Clark, Corporate Cooperation in the Face of Government Investigations, HEALTH LAW, Apr. 2005, at 20.

3. See Geraldine Szott Moohr, Prosecutorial Power in an Adversarial System: Lessons from Current White Collar Cases and the Inquisitorial Model, 8 BufF. CrIM. L. REV. 165, 173 (2004); see also John C. Coffee, Jr., Does "Unlawful" Mean "Criminal"?: Reflections on the Disappearing Tort/Crime Distinction in American Law, 71 B.U. L. REV. 193, 235-38 (1991) (discussing the social and punitive distinctions between civil and criminal sanctions and noting the special "stigma" that attaches to criminal reprimand).

4. See, e.g., Andrew Weissmann \& David Newman, Rethinking Criminal Corporate Liability, 82 IND. L.J. 411, 414 (2007) (detailing the potentially lethal consequences of criminal indictment for a corporation); see also George Ellard, Making the Silent Speak and the Informed Wary, 42 AM. CRIM. L. ReV. 985, 987 (2005) (describing criminal indictment as "lethal, even for venerable institutions"). 
may not recover even if it is actually innocent-just ask the former employees of Arthur Andersen. ${ }^{5}$

Corporate criminal liability has become the subject of piqued criticism not only here but also in the international business community. From a comparative perspective, such liability marks the United States as relatively unique. Few other Western countries impose entity liability, and those that do impose it comparatively infrequently and under the threat of far less serious punitive consequences. In countries like France and Germany, for example, the principle of societas delinquere non potest-"a legal entity cannot be blameworthy" - long prevented imposition of entity criminal liability at all. ${ }^{6}$ More recently, France and several other European nations have cautiously experimented with corporate criminal liability. ${ }^{7}$ Germany has held fast in refusing to punish criminally corporations for the acts of their individual directors or employees. ${ }^{8}$

The question of why the United States - and the United States virtually alone-imposes such significant corporate criminal liability has been the subject of limited scholarly attention. Those who have studied the field espouse varying rationales for America's unique position. Some have argued that the American system grew out of the common law tradition, one that historically embraced the legal fiction - prevalent in corporate law - of the business entity as a separate being. ${ }^{9}$ Others have focused on the Continental system's use of

5. Arthur Andersen was convicted at trial of obstruction of justice. The company folded shortly after the conviction. The fact that U. S. Supreme Court would later overturn that conviction on a technicality related to the jury charge was of little consolation to the thousands of employees rendered jobless. See Elizabeth K. Ainslie, Indicting Corporations Revisited: Lessons of the Arthur Andersen Prosecution, 43 AM. Crum. L. REV. 107 (2006).

6. See Sara Sun Beale \& Adam G. Safwat, What Developments in Western Europe Tell Us About American Critiques of Corporate Criminal Liability, 8 BUFF. CRIM. L. REV. 89, 105 (2004).

7. See Luca Enriques, Bad Apples, Bad Oranges: A Comment from Old Europe on Post-Enron Corporate Governance Reforms, 38 WAKE FOREST L. REV. 911 (2003) (noting recent developments in European countries in the context of corporate criminal liability); Roland Hefendehl, Corporate Criminal Liability: Model Penal Code Section 2.07 and the Development in Western Legal Systems, 4 BUFF. CRIM. L. REV. 283 (2000) (same). For a discussion of developments in France, see Leonard Orland \& Charles Cachera, Corporate Crime and Punishment in France: Criminal Responsibility of Legal Entities (Personnes Morales) Under the New French Criminal Code (Nouveau Code Pénal), 11 CoNN. J. INT'L L. 111 (1995).

8. See Beale \& Safwat, supra note 6 .

9. See Kathleen F. Brickey, Corporate Criminal Accountability: A Brief History and an Observation, 6o WASH. U. L.Q. 393, 404-15 (1982) (providing an excellent history of the development of the American doctrine); Weissmann \& Newman, supra note 4, at 417-23 (tracing the history of the development of the American doctrine of corporate criminal liability); see also infra notes 21-39 and accompanying text. 
administrative regulations and civil law remedies to hold corporate malfeasance in check, arguing that those approaches are the functional equivalent of criminal liability in America. ${ }^{10}$ Finally, and more broadly, some have suggested that American punishment of white-collar crime is but another manifestation of this country's more general penchant for overcriminalization and harsh punishment of crime-harsh, that is, in comparison to other countries like Germany. ${ }^{11}$

Each of these explanations is surely right, at least in part, and yet each is just as surely incomplete. For example, Germany and France regulate corporate behavior largely through administrative and civil laws, but so does the United States. What makes America so unique is that it imposes significant criminal liability in addition to those administrative and civil regulations. Similarly, while it is certainly true that American law developed out of the common law tradition, one that has never embraced societas delinquere non potest, the United States has embraced a far more aggressive and far-reaching form of corporate criminal liability than any other common law country, most notably England. ${ }^{12}$ Indeed, corporations today routinely take refuge from the harsh American regulatory system by listing themselves, not in a Continental law market, but on the London Stock Exchange. ${ }^{13}$

What, then, if anything, can explain the uniquely American propensity to hold corporations criminally liable and to maintain the fiction of entity culpability? This Note attempts to answer that question by placing corporate criminal liability within the broader context of the nation's criminal justice system. Comparing the United States to Germany, this piece argues that

10. See, e.g., Enriques, supra note 7, at 920 (noting that Germany responded to Enron and other recent scandals by making civil and administrative remedies more available).

n. See James Q. Whitman, Harsh Justice: Criminal Punishment And the Widening Divide BETWEEN AMERICA AND EUROPE (2003); Coffee, supra note 3, at 195-96, 203-08 (discussing the expansion of the American criminal code to reach corporate malfeasance and whitecollar crimes that other countries regulate through tort law).

12. See Beale \& Safwat, supra note 6; see also Jeffrey S. Parker, Doctrine for Destruction: The Case of Corporate Criminal Liability, 17 MANAGERIAL \& DECISION ECON. 381, 382 (1996) ("Even within those legal systems largely based on the English legal tradition-Britain, Canada, Australia, New Zealand, and the United States - corporate criminal liability heretofore has been more of a theoretical anomaly than a significant practical reality.").

13. See Comm. on Capital Mkts. Regulation, Interim Report 2-3, 29-34, 39-44 (2006) (referencing data suggesting a shift in initial public offerings from New York to London in the wake of the Sarbanes-Oxley Act); MCKINSEY \& Co., SUSTAINING NEW YORK'S AND THE US' GLOBAL FINANCIAL SERVICES LEADERSHIP 10-14, 16-17 (2007) (same); see also Lawrence A. Cunningham, Beyond Liability: Rewarding Effective Gatekeepers, 92 MINN. L. REv. 323 (2007) (discussing corporations' responses to American and international regulatory developments). 
corporate criminal liability is not so much the result of increased American interest in penalizing or regulating corporate behavior but rather a unique response to, and manipulation of, American criminal procedure and the process by which the American criminal justice system operates.

The argument proceeds as follows: in the United States, criminal defendants enjoy significant procedural protections that are either unavailable or available in more limited form in Germany. The American Constitution of course affords all criminal defendants a bevy of protective rights that make it more difficult for prosecutors to interrogate a defendant or uncover evidence. ${ }^{14}$ In the context of white-collar crime in particular, the protection of greatest significance is the corporate attorney-client privilege, a privilege that has been read expansively by American courts to shield virtually any conversation between in-house counsel and employees related to their work. ${ }^{15}$

Moreover, American defendants engaged in an adversarial system are guaranteed the assistance of defense counsel, who in turn are given significant tools to slow an investigation, block the admissibility of evidence, and combat a conviction at every stage of the proceeding. These difficulties, much like the evidentiary burdens, are only exacerbated in the context of white-collar criminal proceedings, in which the underlying facts are likely to be particularly complex, the investigations particularly time consuming, and the defense counsel particularly skilled.

But, in return, the American system gives prosecutors tools that simply are not available to prosecutors in countries like Germany: American prosecutors have the power to determine whether to bring charges, and if so, what charges to bring. Moreover, those prosecutors can negotiate plea bargains and demand that defendants cooperate with an investigation in return. It is by exercising those powers that corporate criminal liability comes into play in the American system: by threatening corporations with the prospect of criminal prosecution, prosecutors force them to plead guilty and then to cooperate in attempts to prosecute and convict individual corporate directors and employees. ${ }^{16}$

14. See generally Stephen A. Saltzburg \& Daniel J. Capra, American Criminal Procedure ( 7 th ed. 2004) (providing an overview of the constitutional underpinnings for many procedural protections enjoyed by American criminal defendants).

15. For a discussion of the privilege, its history, and its scope, see infra notes 108-113 and accompanying text.

16. See Weissmann \& Newman, supra note 4, at 414 ("In the post-Enron world, it is the rare corporation that will risk indictment by the Department of Justice (DOJ), let alone a trial. The financial risks are simply too great. Knowing this, the government has virtually unfettered discretion to exact a deferred prosecution agreement from a corporation ...."). 
Cooperation, in turn, often involves taking steps to help prosecutors convict the individual employees also under investigation. Under the guise of "cooperation," federal prosecutors have compelled corporations to waive the attorney-client privilege, to complete thorough internal investigations and turn over any results to prosecutors, and perhaps most controversially, to cut off the advancement of attorneys' fees to individual employees under investigation. ${ }^{17}$ Not surprisingly, therefore, when a corporation pleads guilty and cooperates, prosecuting the employees at the center of alleged corporate fraud becomes remarkably easier.

This Note thus argues that corporate criminal liability in the United States has developed, at least in significant part, because of the acts of American prosecutors. Conceptualizing corporate criminal liability in the United States as a tool used by prosecutors to manipulate unique aspects of American criminal procedure in an attempt to convict individual employees both helps to explain why it has taken on such a prominent role in the American adversarial system and why it has not similarly blossomed in so many European ones. Indeed, characterizing entity liability as a prosecutorially driven doctrine explains both its rapid growth in application and the vitriol it inspires in the business community-attributes that do not attach to corporate criminal liability in even those foreign countries that have vibrant doctrines of entity liability. ${ }^{18}$

17. See infra notes 181-183 and accompanying text. Under intense criticism and in response to at least one court's holding that the practice raised constitutional concerns, the U.S. Department of Justice recently revised its internal guidelines for federal prosecutors. In December 2006, the department issued the "McNulty Memorandum." Memorandum from Paul J. McNulty, Deputy Att'y Gen., to Heads of Dep't Components and U.S. Att'ys (Dec. 12, 2006) [hereinafter McNulty Memo], available at http://www.usdoj.gov/dag/speeches/ 2006/mcnulty_memo.pdf. That memorandum replaced the Thompson Memorandum, which had established Department of Justice policies for prosecuting corporations. See infra note 176 . The McNulty Memorandum dictated that, as a matter of internal policy, federal prosecutors should no longer consider whether a corporation has advanced attorneys' fees to its employees in deciding if the corporation has cooperated. See McNulty Memo, supra, at 11. As this Note went to press, the Department announced further revisions to its policies that would preclude federal prosecutors from forcing a corporation to waive the attorney-client privilege. See Robert Schmidt, Justice Dept. Reining in Prosecutors: New Guidelines Issued for Corporate Fraud Cases, WASH. POST, Aug. 29, 2008, at Do3; see also United States v. Stein, 435 F. Supp. 2d 330 (S.D.N.Y. 2006) (finding government pressure on a corporation to cut off advancement of attorneys' fees to individual employees under investigation violated the Fifth and Sixth Amendment rights of those employees).

18. The Dutch, for example, have long maintained forms of entity liability comparable in scope to the American system, see Hefendehl, supra note 7 at 288 , but corporate prosecutions are far more rare - and far less criticized - than they have been in the United States. See Beale \& Safwat, supra note 6, at $111 \mathrm{n} .94$; see also Hans de Doelder, Criminal Liability of 
To make its case, this Note will directly compare the systems of the United States and Germany. While a number of European nations could serve as appropriate foils to the American regime, for the purposes of this discussion, Germany serves as a particularly apt model for comparison. France, England, Italy, and several other European countries have recently begun cautiously to experiment with corporate criminal liability, but Germany has remained steadfast in refusing to hold corporations criminally liable. The contrast between the German and American systems, thus, is most stark, providing the ideal basis for this comparative project. ${ }^{19}$

Relying on that stark contrast, this Note argues that the differences between the American and German systems do not stem primarily from different conceptions of what constitutes a crime but rather from the very different criminal justice systems that the two countries employ. It shall take as its starting point the fact that both countries adopt traditional conceptions of white-collar crime; fraud, for example, is illegal in both. The differences in how those crimes are investigated and prosecuted, however, drives the discrepancies in corporate criminal liability.

In Germany, corporations face no prospect of criminal liability. But they also have no power to thwart the investigation and prosecution of individual employees. There is no corporate attorney-client privilege, for example, or any general practice of aiding individual employees under investigation through indemnification. In the United States, the paradigm is reversed: corporations enjoy an attorney-client privilege and routinely assist individuals under investigation. They also face the threat of criminal prosecution. But as suggested above, rarely, if ever, do those corporations actually go to trial. Instead, in return for agreements to waive the privilege, to deny indemnification to employees, and to cease any support provided to those individuals under investigations, corporations are given deals-generally

Corporations - Netherlands, in CRIMINAL LIABILITY OF CORPORATIONS 289, 291-92 (Hans de Doelder \& Klaus Tiedemann eds., 1996) (noting that while Dutch prosecutors now can impose entity liability, they often prefer to impose liability on natural persons instead).

19. Germany, as a large, industrial economy, also serves as an excellent model of comparison for financial and procedural reasons as well. Indeed, the German-American comparison has provided the basis for much of the most important work in comparative law, and comparative criminal procedure in particular, in the last fifty years. See, e.g., MIRJAN R.

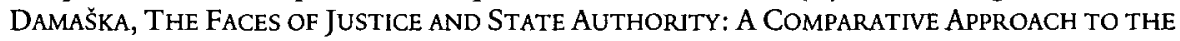
Legal Process (1986); John H. Langbein, Comparative Criminal Procedure: Germany (1977); James Q. Whitman, Consumerism Versus Producerism: A Study in Comparative Law, 117 YALE L.J. 340 (2007) (comparing the American economy with the German and French economies). 
deferred prosecution agreements. ${ }^{20}$ American prosecutors and corporations thereby leverage their unique powers, bargaining for an outcome that looks remarkably similar to the German system: corporations forfeit any protections and avoid criminal liability, and individual wrongdoers are aggressively pursued and prosecuted.

This Note proceeds in four parts. Part I of this Note provides a brief overview of the development of entity liability in both countries. This history suggests that prosecutors, rather than legislative bodies, have played a critical role in crafting the American doctrine. Part II presents the crux of the Note's argument, drawing distinctions between the American and German criminal justice systems in two main areas: the gathering and presentation of evidence, and the powers and roles of prosecutors. Taken as a whole, these differences create a German system that facilitates the investigation of individual wrongdoers and an American system that stymies similar prosecutions. Part II also demonstrates how American prosecutors use their unique powers to compel corporations to cooperate, thereby enabling them to prosecute the same type of individuals that the German system pursues. This Note concludes by offering further thoughts on how the argument presented here can shape not only the way scholars think about corporate criminal liability in both countries, but also how lawmakers and practitioners think about reforming the American system.

\section{COMPARATIVE CORPORATE CRIMINAL LIABILITY}

\section{A. The United States}

Until the eighteenth century, the concept of convicting a corporation of a crime had generally been rejected out of hand. Many believed an entity simply lacked the moral blameworthiness to be brought within the domain of the criminal justice system. ${ }^{21}$ Literalists were troubled by the fact that a corporation could not physically be haled before a court. ${ }^{22}$

20. See infra notes 172-192.

21. See John C. Coffee, Jr., Corporate Criminal Responsibility, in 1 ENCYCLOPEDIA OF CRIME AND JUSTICE 253, 253 (Sanford H. Kadish ed., 1983). For an excellent history of the development of corporate criminal liability in the United States and England, see generally AMANDA Pinto \& Martin Evans, Corporate Criminal liability 3-17 (2003); and V.S. Khanna, Corporate Criminal Liability: What Purpose Does It Serve?, 109 HARV. L. REV. 1477 (1996).

22. See L.H. Leigh, THE Criminal Liability of Corporations in ENGLiSH LAW 3-12 (1969). 
In the United States, those attitudes began to soften during the course of the nineteenth century when corporations in American society first began to blossom and their potential to do harm first became significant. ${ }^{23}$ By the turn of the twentieth century, as the Industrial Revolution fundamentally altered the role of large corporations in American life, the need for some mechanism of regulating and punishing corporate malfeasance became all the more clear. ${ }^{24}$

Most histories of American corporate criminal liability ${ }^{25}$ start there - the Industrial Revolution, the rise of the regulatory state, and the Supreme Court's landmark 1909 decision in New York Central \& Hudson River Railroad v. United States. ${ }^{26}$ In New York Central, the Court upheld the constitutionality of the Elkins Act, a federal statute regulating railway rates that imposed criminal liability on corporations that violated the statute's mandates. In sweeping language, the Court rejected the corporation's contention that, as an entity, it could not commit a crime, finding Congress had expansive power to regulate interstate commerce that included the authority to impose criminal sanctions. The Court was untroubled by the legal fiction that an entity could neither take criminal action nor possess criminal intent. Instead, the Court adopted the civil law doctrine of respondeat superior, holding that a corporation could constitutionally be convicted of a crime when one of its agents had committed a criminal act (1) within the scope of his or her employment, and (2) for the benefit of the corporation. ${ }^{27}$ That standard remains good law to this day.

Beginning the history of American entity liability with New York Central is certainly logical because the case established the authority of Congress to

23. For an excellent history of the correlation between the development of corporate criminal liability and the growing influence of corporations in modern life, see Brickey, supra note 9 , at 393, 396-97 (noting that "as the corporate form became more common," attitudes toward corporate criminal liability "changed dramatically" and "common-law judges devised a theory of corporate accountability for crime").

24. See Parker, supra note 12 , at $386-87$ (linking the development of corporate criminal liability directly to the Industrial Revolution and concluding that the doctrine developed fastest where the Industrial Revolution was most robust); see also Jeffrey S. Parker, The Blunt Instrument, in DeBATING CORPORATE CRIME 71, 76-77 (William S. Lofquist, Mark A. Cohen \& Gary A. Rabe eds., 1997) (asserting that the development of the American doctrine is "attributable to a unique confluence of economic and legal conditions in Britain and America" in the "mid-nineteenth century").

25. See, e.g., KathleEN F. Brickey, Corporate and White Collar Crime: Cases and MATERIALS 1 (3d ed. 2002) (opening discussion of corporate criminal liability with reproduction and analysis of New York Central); JEROLD H. ISRAEL ET AL., WHITE COLLAR Crime: LaW and PRACTICE 43 (2d ed. 2003) (same); Julie R. O'Sullivan, Federal White Collar Crime: Cases and Materials 162 (3d ed. 2007) (same).

26. 212 U.S. 481 (1909).

27. Id. at 494 . 
criminalize corporate conduct. But doing so overlooks a very important movement that was afoot well before New York Central, one that is critical to understanding how and why entity liability expanded so rapidly in its wake. While New York Central involved a statute that explicitly extended criminal liability to corporations, for some fifty years before Congress passed the Elkins Act, prosecutors across the country had been creatively pursuing criminal sanctions against corporations by applying general criminal laws-laws that, by their terms, did not extend to corporations as entities - to corporate conduct.

Indeed, as early as the 1850 , prosecutors in states like New Jersey and Pennsylvania aggressively pursued criminal charges against corporations by applying common law criminal doctrines-most commonly, the crime of nuisance - to corporations as entities, despite the facts that the common law did not recognize the concept of entity liability and state laws made no explicit mention of entity liability. ${ }^{28}$ Corporations often challenged these prosecutions with little success on the very grounds that, as entities, they could not be charged with or convicted of crimes. ${ }^{29}$ For the most part, state supreme courts affirmed the validity of such convictions, finding, for example, that a criminal "indictment and an information are the only remedies to which the public can resort for a redress of their grievances." ${ }^{30}$

As courts repeatedly upheld such convictions, prosecutors became emboldened, indicting corporations not just for common law crimes but also for statutory offenses, even when the statute made no specific mention of entity liability. Prosecutors in Alaska, for example, indicted a corporation whose employees had violated a statute prohibiting salmon fishing, concluding that for purposes of the statute, the employees' conduct and mental state could be imputed to the corporation..$^{31}$ Judges, for their part, while acknowledging that

28. See Commonwealth v. Proprietors of New Bedford Bridge, 68 Mass. (2 Gray) 339 (1854); State v. Morris \& Essex R.R. Co., 23 N.J.L. 360 (1852). Similar cases arose in a number of other states. See, e.g., President of Susquehanna \& Bath Turnpike Rd. Co. v. People, 15 Wend. 267 (N.Y. Sup. Ct. 1836); Pittsburgh, Va. \& Charleston Ry. Co. v. Commonwealth, 101 Pa. 192 (1882); State v. Corp. of Shelbyville, 36 Tenn. (1 Sneed) 176 (1856).

29. There were some state courts that refused to allow prosecutors to extend criminal laws of general applicability to corporations, refusing, absent explicit legislative directive, to consider a corporation to be a "person" for purposes of those states' criminal codes. See, e.g., State v. Terre Haute Brewing Co., 115 N.E. 772 (Ind. 1917); State v. Cincinnati Fertilizer Co., 24 Ohio St. 611 (1874); Judge Lynch Int'l Book \& Publ'g Co. v. State, 208 S.W. 526 (Tex. Crim. App. 1919); see also Henry W. Edgerton, Corporate Criminal Responsibility, 36 YALE L.J. 827, 829-31 (1927) (discussing early state case law).

3o. People v. Corp. of Albany, 11 Wend. 539, 543 (N.Y. Sup. Ct. 1834).

31. United States v. Alaska Packers' Ass'n, 1 Alaska 217 (1901). 
many of these amounted to "test cases," ${ }^{22}$ continued to acquiesce, relying not on statutory text or theoretical arguments but rather on what could charitably be termed policy rationales. As the Massachusetts Supreme Judicial Court noted in explaining away the historical lack of corporate criminal liability, "[e]xperience has shown the necessity of essentially modifying [that rule]."

The true origins of American criminal liability, in other words, did not lie in legislative efforts, nor did they result from policy debates or logically crafted statutory choices. Rather, the drive toward entity criminal liability stemmed primarily from the efforts of American prosecutors who creatively and aggressively applied statutory and common law and from the early American courts that allowed them to do so.

That more complete narrative is crucial to understanding why New York Central marked such a turning point in the history of American entity liability. By confirming that a corporation could constitutionally be prosecuted for a crime under a theory of respondeat superior, the Court validated a practice that had been pursued with increasing frequency by prosecutors for more than fifty years. Thereafter, with the Court's stamp of approval, prosecutors continued to aggressively pursue the type of "creative lawyering" they had before, applying both the common law and statutory offenses to corporate conduct.

Federal prosecutors in particular seized upon the Court's ruling to expand the reach of federal criminal law. Recognizing that all federal criminal laws apply to "any person" who violates them and that Congress had defined the term "person" to include "corporations" for purposes of the U.S. Code more generally, ${ }^{34}$ federal prosecutors began applying the criminal code to corporate conduct. In the years immediately following New York Central, federal prosecutors charged corporations with individual crimes such as knowingly mailing obscene materials, ${ }^{35}$ conspiring to transport liquor onto Indian

32. See, e.g., id. at 225 .

33. Proprietors of New Bedford Bridge, 68 Mass. at 345. Even the U.S. Supreme Court, in upholding Congress's creation of corporate criminal liability in New York Central, seemed to rely as much on policy rationales as it did on legal principles. Acknowledging the law's historical aversion to corporate criminal liability, the Court argued that rejecting such practice was now permissible because the law "cannot shut its eyes to the fact that the great majority of business transactions in modern times are conducted through [corporate] bodies, and particularly that interstate commerce is almost entirely in their hands." N.Y. Cent. \& Hudson R.R. Co. v. United States, 212 U.S. 481, 495 (1909).

34. See 1 U.S.C. $\$ 1$ (2000) ("[T]he words 'person' and 'whoever' include corporations, companies, associations, firms, partnerships, societies, and joint stock companies, as well as individuals.").

35. United States v. N.Y. Herald Co., 159 F. 296 (C.C.S.D.N.Y. 1907). 
territory, ${ }^{36}$ violating the Espionage Act, ${ }^{37}$ and manslaughter. ${ }^{38}$ And lower courts, faced with the expansive holding in New York Central, went along, finding the lack of any specific congressional directive that a particular criminal law be applied to corporations to be, in most cases, irrelevant. ${ }^{39}$

This is not to suggest that Congress had nothing to do with the expansion of entity liability. To the contrary, both before and after New York Central, Congress enacted thousands of statutes creating new or additional criminal liability for corporations. The Securities Act of 1934, the Food, Drug, and Cosmetic Act, and the Interstate Commerce Act are some of the more wellknown and commonly applied statutes passed in the last century that include specific provisions for corporate criminal liability. ${ }^{40}$ Perhaps more important to this narrative, Congress has enacted thousands of other statutes - statutes that do not make explicit mention of corporate criminal liability - that aggressive prosecutors have had little difficulty extending to corporate conduct, including the mail and wire fraud statutes and the Racketeer Influenced and Corrupt Organizations (RICO) Act. ${ }^{41}$ Moreover, Congress has remained silent in the wake of those extensions, despite the fact that there is nothing to suggest that, by defining a "person" to include a "corporation" for purposes of the entire U.S. Code, Congress thought it was altering the longstanding common law tradition that entities could not be held criminally liable. ${ }^{42}$

Nevertheless, the above narrative should at least underscore the very significant-and for comparative purposes, very unique-role American

36. Joplin Mercantile Co. v. United States, 213 F. 926 (8th Cir. 1914).

37. United States v. Am. Socialist Soc'y, 26o F. 885 (S.D.N.Y. 1919).

38. United States v. Van Schaick, 134 F. 592 (C.C.S.D.N.Y. 1904).

39. See supra notes $35-38$. For the most thorough discussion of this history, see Brickey, supra note 9 , at $405^{-15}$.

40. Securities Exchange Act of 1934, 15 U.S.C. $\$ 78 c(a)(1)$ (2000); Food, Drug, and Cosmetic Act, 21 U.S.C. $\$ 321(\mathrm{e})(2000)$; Interstate Commerce Act, 49 U.S.C. $\$ 11,907$ (2000).

41. While somewhat out of date at this point, the best history of this expansion is Coffee, supra note 3. See also Khanna, supra note 1.

42. The legislative history of 1 U.S.C. $\$ 1$ is virtually nonexistent and certainly makes no mention of corporate criminal liability. See 1947 U.S.C.C.A.N. 1512 (noting in its most recent, significant amendment, congressional intent to broaden the scope of $\$ 1$ generally but making no mention of corporations or criminal liability); see also Note, Decisionmaking Models and the Control of Corporate Crime, 85 YALE L.J. 1091, 1092-99 (1976) (tracing the history of American corporate criminal liability, noting that much of it is premised on $§ 1$ 's definition of the term "person" as including a corporation, and concluding that "[b]ecause of the imprecision of statutory language, the courts rather than Congress have been primarily responsible for delimiting the circumstances under which corporate entities are criminally liable"). 
prosecutors played in crafting the modern doctrine of corporate criminal liability. Given the authority to apply the entire criminal code to corporations, prosecutors could and did make the decision to extend the reach of the criminal law. Courts, for the most part, affirmed those extensions and the corporate convictions that accompanied them without question, objecting only occasionally where prosecutors sought to charge a corporation with crimes such as rape, murder, or bigamy. ${ }^{43}$ That courts imposed some limits on prosecutors is, of course, of interest. But of far greater importance for the purposes of this discussion is the fact that an American prosecutor would even attempt to prosecute a corporation for rape in the first place.

Today, the scope of corporate criminal liability is immense. A corporation can be prosecuted under virtually any general criminal provision-including mail and wire fraud statutes, ${ }^{44}$ money laundering statutes, ${ }^{45}$ and extortion statutes ${ }^{46}$ - or for almost any other conduct that might fall within the purview of what is considered white-collar crime. By some estimates, there are more than three hundred thousand federal offenses with which a corporation could be charged. ${ }^{47}$ For the corporation to be convicted, the New York Central test still applies: prosecutors need only establish that a corporate agent committed an illegal act while acting within the scope of his employment and intending to benefit the corporation. ${ }^{48}$

Moreover, the term "agent" and the "intent to benefit" test have been read quite expansively by lower courts. Courts have routinely found that a low-level employee is acting "within the scope of his employment" with an "intent to benefit" the corporation when he is acting in a manner expressly forbidden by the company's own internal policies. ${ }^{49}$ Corporations can be held criminally

\footnotetext{
43. See Khanna, supra note 21 , at 1484.

44. 18 U.S.C. $\$ 1341,1343(2000)$.

45. Id. $\$ \$ 1956-1957$.

46. Extortion and blackmail are covered in several places in the U.S. Code, depending on the nature and target of the alleged scheme. See id. $\$ 872-877,1951-1952$.

47. Khanna, supra note 1 , at 99-100.

48. Id. at 98-100; see supra text accompanying note 27.

49. See United States v. Automated Med. Labs., Inc., 770 F.2d 399, 407 (4th Cir. 1985) ("The fact that many of [the employees'] actions were unlawful and contrary to corporate policy does not absolve [the defendant-corporation] of legal responsibility for their acts."); United States v. Hilton Hotels Corp., 467 F.2d 1000, 1007 (9th Cir. 1972) (holding that the company can be found liable "for the acts of its agents in the scope of their employment, even though contrary to general corporate policy and express instructions to the agent"). Moreover, as noted, under current law, corporations are equally liable regardless of whether the "agent" in question is a top-level manager or a low-level secretary. See, e.g., Riss \& Co.v. United States, 262 F.2d 245, 250 (8th Cir. 1958) (finding liability for the conduct of a clerical
} 
liable whether or not management was aware of the conduct in question, and they may receive no leniency for having a compliance or oversight system in place. $^{50}$

As a result, corporations are routinely threatened and actually prosecuted for the conduct of individual employees despite the fact that there may be considerable doubt about whether Congress ever intended for such conduct to create criminal liability for the corporation as an entity. Consider as one tragic recent example the prosecution of accounting giant Arthur Andersen for obstruction of justice relating to its audits of Enron in the years before Enron's collapse. ${ }^{51}$ The trial judge instructed the jury that it had to find the company guilty if the prosecutor had established that any employee had ever acted with an "intent to subvert, undermine, or impede the fact-finding ability of an official proceeding." ${ }^{52}$ Not surprisingly, the jury reached a guilty verdict having been so charged, the jury likely could have found almost any American corporation guilty. ${ }^{53}$

Once convicted, a corporation faces statutory penalties that can be exceptionally high, particularly from a comparative perspective. ${ }^{54}$ Under a separate set of corporate sentencing guidelines, ${ }^{55}$ American law imposes fines

worker); United States v. George F. Fish, Inc., 154 F.2d 798, 801 (2d Cir. 1946) (finding liability for the conduct of a salesman).

50. See generally Weissmann \& Newman, supra note 4 , at 423 (noting that under current American doctrine, "the corporation can be held liable for agents no matter what their place in the corporate hierarchy and regardless of the efforts in place on the part of corporate managers to deter their conduct").

51. For an excellent discussion of the case and its questionable expansion of the crime of obstruction of justice, see Ainslie, supra note 5.

52. See United States v. Arthur Andersen, LLP, 374 F.3d 281, 293 (5th Cir. 2004). Indeed, the trial judge went on to instruct the jury that it could convict Arthur Andersen "even if [the company] honestly and sincerely believed that its conduct was lawful." Arthur Andersen, LLP v. United States, 544 U.S. 696, 706 (2005). The judge's jury charge was the basis for a subsequent appeal and rare reversal by the U. S. Supreme Court. See id. at 708 . The Court found the judge's instruction deficient in that it failed to require the jury to find that the defendant had acted with a "corrupt" or improper intent to impede a government investigation. $I d$. at 705 -06.

53. To its credit, the Andersen jury may well have realized the perilous slippery slope it sat atop-despite Andersen's clear-cut liability under the law, the jury spent more than ten days deliberating. See Arthur Andersen, 544 U.S. at 702; Kurt Eichenwald, Andersen Guilty in Effort To Block Inquiry on Enron, N.Y. TIMES, June 16, 2002, at 1.

54. See generally WHITMAN, supra note in (discussing in depth the comparative harshness of American punishments).

55. For an excellent discussion of the corporate sentencing guidelines, their current applicability, and several proposals for change, see Timothy A. Johnson, Note, Sentencing Organizations After Booker, 116 YALE L.J. 632 (2006). 
that can run into the hundreds of millions of dollars for each offense. Moreover, any corporation convicted of a felony may be permanently barred from doing business with government agencies or participating in government programs, a deprivation that can singlehandedly destroy producers in sectors from aeronautics (no defense contracts) to pharmaceuticals (no federal funding for drug research, no reimbursement for welfare recipients receiving medication). ${ }^{56}$ Finally, the reputational costs can be devastating-the announcement that the government is even considering criminal charges can send a company's stock price tumbling, create immediate management shakeups, or worse. ${ }^{57}$

There are two final notes worth emphasizing for the purposes of this comparative discussion. First, as was true under the Elkins Act, prosecutors retain the discretion to bring charges against the corporation in addition to - not in lieu of - any charges brought against the individual officers or employees in their personal capacity. Indeed, as discussed in Part II, the fact that both individuals and corporations simultaneously face criminal charges is critical to understanding the role entity criminal liability plays: by charging both the corporation and the individuals, American prosecutors rather artificially create codefendants, and as is so often the case in the American system, one defendant can then be compelled to plead guilty and cooperate in the prosecution of a codefendant. ${ }^{58}$

Second, corporate criminal liability in no way displaces the extensive regulatory scheme to which corporations are also subjected. American agencies such the Food and Drug Administration (FDA), Securities and Exchange Commission (SEC), and the Federal Trade Commission (FTC) all have regulatory and enforcement powers. ${ }^{59}$ Such agencies often regulate virtually every aspect of American business, and more important, can use their

56. The process, known as "debarment," is governed by the Code of Federal Regulations and authorizes agency officials to debar any corporation convicted of certain felonies, including "embezzlement, theft, forgery, bribery, falsification or destruction of records, making false statements, tax evasion, or receiving stolen property" or any felony "in connection with (i) obtaining, (ii) attempting to obtain, or (iii) performing a public contract or subcontract." Debarment, Suspension, and Ineligibility, 48 C.F.R. $\$ 9.406-2(a)(1)-(3)$ (2007).

57. See Weissmann \& Newman, supra note 4 , at 440-41. For an interesting discussion of the market effects of the disclosure of criminal investigations on stock prices, see Pamela $\mathbf{H}$. Bucy, Why Punish? Trends in Corporate Criminal Prosecutions, 44 AM. CRIM. L. ReV. 1287, 1288-89 (2007) (collecting data on Enron, Adelphia, and WorldCom, among others).

58. See infra notes 156-158.

59. For a general discussion of agency enforcement powers and their relationship to simultaneous criminal investigations ("parallel proceedings"), see O'SULLIVAN, supra note 25 , at $1097-98$. 
enforcement power to investigate and "prosecute" alleged wrongdoing. ${ }^{60}$ All such agencies can impose significant fines for violations of their regulations and can issue rulings and public statements that carry devastating reputational costs for those targeted. ${ }^{61}$

The critical point, therefore; is that American corporate criminal liability sits atop a pile of punitive and regulatory remedies, as just one very significant weapon in the government's arsenal.

\section{B. Germany}

The story of corporate criminal liability in Germany is considerably shorter: put simply, there is no corporate criminal liability in Germany. Like so much of Western Europe, Germany has long resisted the legal fiction that a corporation could commit a crime. Embracing the principle of societas delinquere non potest, the German system instead punishes individual corporate officers and punishes them harshly, especially within the context of a legal regime that is often considered lenient in comparison to the American system. ${ }^{62}$ To this date, Germany continues to resist corporate criminal liability, even as many of her neighbors in Western Europe have tentatively begun to change course in response to recent corporate scandals in the United States and Europe. ${ }^{63}$

This is not to say the Germans have turned a blind eye to the need to regulate corporate behavior and punish corporate malfeasance. But it is to say that they have done so in a different manner: Germany extends its criminal law to individual corporate directors and agents and punishes them for many of the same crimes American directors could be accused of, including all forms of theft and fraud. Germany then relies on administrative and civil law remedies to regulate and punish the corporation itself.

German laws targeting individual, white-collar criminal conduct are considerably newer than their American counterparts: the first and second

6o. It is worth noting that agencies, much like federal prosecutors, possess virtually uncabined discretion to choose which charges to pursue against which potential targets, and can interpret and stretch the regulatory law in the process. See, e.g., SEC v. Chenery Corp., 332 U.S. 194 (1947) (holding that the agency has power to promulgate new rules and interpretations of existing rules through individual enforcement actions).

61. See generally Marshall B. Clinard \& Peter C. YEAger, Corporate Crime 77-109 (2006) (discussing agency regulation of corporations, its influence on corporate behavior, and corporate criticism of that influence); O'SULLIVAN, supra note 25, at 1097-1136 (discussing parallel proceedings by agencies and federal prosecutors).

62. See Beale \& Safwat, supra note 6, at 107-23.

63. See id. 
German "Acts Combating White Collar Crime" were passed in $1976^{64}$ and $1986,{ }^{65}$ respectively. Over the last three decades, however, Germany has rapidly expanded the reach of its white-collar criminal laws, ${ }^{66}$ reduced certain evidentiary burdens necessary for conviction, and, at the same time, increased the maximum penalties. Today, the reach of those laws is substantial and their impact significant, and recent extensions have even sparked criticism that German white-collar criminal laws have been overextended to include conduct that could better be handled through the regulatory or administrative systems. $^{67}$

It is worth noting for comparative purposes that all such expansions have come directly from explicit legislative changes. As is discussed in far greater detail in Part II, German prosecutors lack the type of far-reaching and virtually unbridled authority that American prosecutors possess and have used to expand entity liability. German prosecutors certainly have not and could not have contributed to defining the reach of German criminal law. ${ }^{68}$

Germany controls and punishes the corporation itself through a system of administrative regulations that come with the prospect of civil liability. The German administrative system is technically overseen by criminal courts, and the penalties imposed can seem quasi-criminal in nature. Fines are the standard punishment and can reach into the millions of Euros. Corporations can also face asset forfeiture and forced repayment of illegally obtained gains. ${ }^{69}$

Despite the undeniably punitive aspect of those fines, however, corporations in the German system are never accused, let alone convicted, of "crimes." Instead, they may commit "order violations." punishment imposed is arguably the same - the corporation pays a monetary fine-the broader "collateral consequences" ${ }^{71}$ that attach to a criminal conviction are not present. Indeed, many of the reputational costs associated

64. Erstes Gesetz zur Bekämpfung der Wirtschaftskriminalität [First Act Combating White-Collar Crime], July 29, 1976, BGBl. I at 2034.

65. Zweites Gesetz zur Bekämpfung der Wirtschaftskriminalität [Second Act Combating White-Collar Crime], May 15, 1986, BGBl. I at 721.

66. See Bernd Schünemann, The Sarbanes-Oxley Act of 2002: A German Perspective, 8 Buff. Crim. L. REV. 35, 36-39 (2004).

67. See id. at 45 (discussing the "common criticism of the German white collar criminal law" that it "use[s] . . criminal law for the enforcement of administrative duties").

68. See generally LANGBEIN, supra note 19 (discussing the role of German prosecutors in comparative terms).

69. See Beale \& Safwat, supra note 6, at 123.

7o. Id. at 123-24; see Hefendehl, supra note 7, at 286.

71. Moohr, supra note 3 , at 173. 
with a corporate criminal conviction in the United States simply do not exist in Germany. Corporations that commit order violations face no further government sanction, and in a society in which civil fines are relatively common and accepted methods of social control, ${ }^{72}$ the market response is generally mild.

\section{Comparison}

The differences between corporate criminal liability in the United States and in Western Europe more generally have attracted increasing scholarly attention, and a variety of different reasons have been articulated for the discrepancies. For the purposes of this argument, it is important to acknowledge at least several of the most significant such arguments and to suggest why each offers an incomplete, if not simply erroneous, explanation.

\section{The Criminal Theorist's Account}

The first and most obvious explanation given for the differing approaches is a pure criminal theory argument. That is, Germany, adhering to the aforementioned principle of societas delinquere non potest, simply does not think a corporation, as an entity, is capable of committing a crime. More generally, as a system premised on truth seeking, the German criminal system could not tolerate the fiction that a corporation had done anything, let alone possessed the mens rea necessary to be convicted a crime. ${ }^{73}$ While such an argument is surely correct on some level, it is unsatisfying, if not incomplete.

From a theoretical perspective, asserting the existence of the principle does little to explain where that principle came from or where its boundaries are drawn: Germany, like virtually every country, is willing to adopt the fiction of a corporation as a separate "person" for purposes of corporate law, bankruptcy law, and even administrative law. ${ }^{74}$ In fact, in some respects, Germany carries

72. See Markus Dirk Dubber, American Plea Bargains, German Lay Judges, and the Crisis of Criminal Procedure, 49 STAN. L. REv. 547, 560-61 (1997); see also Coffee, supra note 3 (highlighting important normative and positive differences between civil and criminal sanctions).

73. See infra notes 115-138; see also Markus Dirk Dubber, Theories of Crime and Punishment in German Criminal Law, 53 AM. J. CoMP. L. 679 (2005) (analyzing the theoretical underpinnings of German criminal law and discussing the significance of theoretical consistency and clarity in the German criminal code generally).

74. For a comparative account of German and American corporate law - and the notion of a corporation as a separate entity in both-see, for example, Theodor Baums \& Kenneth E. 
the fiction further than American law. For example, Germans speak of corporations as having "privacy" rights, which can prevent the type of civil discovery that is so prevalent in American litigation. ${ }^{75}$ Simply to assert, therefore, that the Germans believe a corporation cannot be blameworthy tells us rather little about why Germany draws that particular line, why a German corporation can be treated as a "person" in other legal contexts, and perhaps most important, why a German corporation can be held administratively accountable or liable for damages in a civil tort action. ${ }^{76}$

Moreover, the criminal theorist's account would seem unable to shed much light on an American doctrine that, by virtually all accounts, has never really been conceptualized-let alone justified-as consistent with, or grounded in, traditional criminal theory. ${ }^{77}$ To accept the criminal theorist's account, one would have to presume that American thinkers had considered and rejected the principle of societas delinquere non potest or had endorsed some different theoretical approach to corporate criminal liability. Neither has generally been true. Instead, as a pair of scholars recently noted, "nearly every scholarly article on this topic ... makes a concession to the effect that 'the doctrine of corporate criminal liability has developed ... without any theoretical justification."”78

The discussion above is not to suggest that the development of American law has completely ignored the theoretical issues at stake. But it should suggest

Scott, Taking Shareholder Protection Seriously? Corporate Governance in the United States and Germany, 53 AM. J. COMP. L. 31 (2005).

75. The privacy rights at question are actually vested in the individual employees-Germany, as a member of the European Union, is required to impose stringent "data protection laws" that prohibit corporations from revealing any private information collected from customers, employees, or other individuals with which it engages. See Marisa Anne Pagnattaro \& Ellen R. Peirce, Between a Rock and a Hard Place: The Conflict Between U.S. Corporate Codes of Conduct and European Privacy and Work Laws, 28 BERK. J. EMP. \& LAB. L. 375, 415-20 (2007). The result, however, is often a shield for corporations from discovery or criminal inquiries to which, for example, American corporations would have no similar defense. See id.; Allen Shoenberger, Privacy Wars: E.U. Versus U.S.: Scattered Skirmishes, Storm Clouds Ahead, 17 IND. INT'L \& COMP. L. ReV. 355 (2007) (discussing differences in privacy law between the United States and the European Union including the recognition of corporate privacy rights in Germany).

76. It is worth noting, however, that German law does not generally allow for punitive damages, unlike American law. This limitation, however, applies with equal force to private and corporate litigants. See Volker Behr, Myth and Reality of Punitive Damages in Germany, 24 J.L. \& COM. 197 (2005).

77. See, e.g., Khanna, supra note 21 , at 1477-78 (noting that "few have questioned in depth the fundamental basis for imposing criminal liability on corporations" and that while the spread of such liability in the United States has provoked "considerable debate, commentators have not comprehensively analyzed why corporate criminal liability exists").

78. Weissmann \& Newman, supra note 4 , at 418. 
that criminal theory has only done so much work in this context, and therefore, that a purely theoretical approach cannot fully explain the differences between the two systems.

\section{The Functionalist Account}

A second, commonly offered explanation-what might be called the "functionalist account"79 - is that Germany merely substitutes individual accountability and administrative oversight for a regime of corporate criminal liability. There is undeniably both truth in, and support for, such a proposition. German legislators and legal theorists provide ample documentary support for the view that administrative regulation in particular and the "order violations" imposed are considered regulatory and punitive mechanisms intended to control corporate malfeasance. ${ }^{80}$ Similarly, those same sources supply evidence that Germans view the punishment of individual corporate wrongdoers as a more satisfying response to white-collar crime than entity liability.

The functionalist account, however, seems to falter when one considers that the United States has individual liability and administrative regulation in addition to corporate criminal liability. As discussed above, individual directors can be prosecuted in the United States under the same laws applied to the corporations themselves, ${ }^{81}$ and American agencies such as the FDA, the SEC, and the more recently created Public Company Accounting Oversight Board $(\mathrm{PCAOB})^{82}$ all possess the ability to investigate and to punish corporations that violate their standards and then to impose fines on offending organizations,

79. Functionalism is a school of comparative law that suggests that every society has the same basic needs-policing corporate behavior, for example-and simply takes different approaches to that same "function." For an overview of the role of functionalist arguments in comparative law, see, for example, Ralf Michaels, The Functional Method of Comparative Law, in THE OXFORD HANDBOOK OF COMPARATIVE LAW 339 (Mathias Reimann \& Reinhard Zimmermann eds., 2006).

80. Beale \& Safwat, supra note 6, at 123-24.

81. See supra note 58 and accompanying text.

82. PCAOB, derisively pronounced "peek-a-boo" by practitioners in the field, was created as part of the 2002 Sarbanes-Oxley Act. While technically a private-sector, nonprofit corporation, the PCAOB possesses government-authorized regulatory and investigative powers, and by statute, has the power both to impose penalties and to make referrals to the SEC for use of its regulatory and enforcement power. For more on the PCAOB and the Sarbanes-Oxley Act generally, see The Public Company Accounting Oversight Board, http://www.pcaob.org (last visited Sept. 22, 2008). 
fines that look and seem remarkably like the "order infractions" used in the German system. ${ }^{83}$

Finally, it is worth noting that in the few European countries that have more recently experimented with corporate criminal liability, such as France, the common sentiment has been that such criminal liability "serve[s] as an additional tool, not a substitute for other ... sanctions against corporations themselves or individuals." ${ }^{4}$ The functionalist account, therefore, seems unable to fully explain the discrepancies between the two countries. To suggest that administrative regulation in Germany takes the place of and serves the same function as criminal liability in the United States seems an intriguing but incomplete answer.

\section{Enron "couldn't happen here"}

A third common explanation for the lack of corporate criminal liability in Germany is the sentiment within the European community more broadly that "[Enron] couldn't happen here." 85 As a result, the argument goes, Europe never took the kind of hard-nosed, punitive approach to regulating corporations that the United States adopted. ${ }^{86}$

The underlying argument - what could be called the "European Innocence" account - was, of course, blatantly wrong. Indeed, "Enron" not only could, but also did happen in Europe shortly after those very critics disavowed that very possibility. In the past three years, two of the largest corporations in Europe have announced internal scandals that easily rival Enron in both significance and scope. In 2004, the Italian giant Parmalat disclosed that some $\$ 8.5$ billion in assets had simply "vanished." ${ }^{87}$ The company changed leadership, and many of the outgoing directors and the company itself now face criminal charges. ${ }^{88}$

83. See supra notes 59-61 and accompanying text.

84. Beale \& Safwat, supra note 6, at 145.

85. Editorial, Ahold Out, ECONOMIST, Mar. 1, 2003, at 12.

86. See id.

87. Gail Edmondson \& Laura Cohen, How Parmalat Went Sour, Bus. WK., Jan. 12, 2004, at 46.

88. See Eric Sylvers, Indictments Are Sought in the Collapse of Parmalat, N.Y. TIMES, Mar. 19, 2004, at W1. Italy, unlike Germany, has more recently expanded entity liability, and therefore Parmalat was eligible to be charged and tried for criminal offenses in addition to its corporate directors. See Emily Backus, Prosecutors Indict 29 in Parmalat Investigation, USA TODAY, Mar. 18, 2004, at 3B. ("[A] new Italian law allows institutions to be tried in addition to their employees"). Of significant relevance to this discussion, that recent expansion followed an attempt at a more general transition in Italy to an adversarial criminal justice system, one that is now far more in line procedurally with the American approach than the 
In 2006, German-based Siemens disclosed that it was under investigation in more than a dozen countries, including Germany and the United States, for allegedly bribing government officials to win government contracts, bidrigging, and a variety of other illegal and anticompetitive practices. ${ }^{89}$

Much as with the other explanations offered, the European Innocence account contains important elements of truth. The rise of corporations as controlling cultural entities took place considerably later in many European countries than it did in the United States, and the corresponding fear of the harm those corporations could do to society is similarly a more recent phenomenon. ${ }^{90}$ The European Innocence argument, therefore, might amply explain why German regulatory and white-collar criminal law blossomed in the 1970s, whereas similar laws in the United States were enacted some three or four decades earlier. This argument might further explain why some European countries have recently begun to expand their administrative regulation or even experiment with corporate criminal liability, in light of evidence that Europe was, in fact, not that innocent after all.

Yet in light of those developments, not to mention the much longer history of administrative oversight in countries like Germany, the European Innocence account feels incomplete, if not erroneous. After all, it is hard to maintain that European societies, and Germany in particular, had wholly failed to recognize the risk of corporate malfeasance in light of the extensive administrative systems in place and the enactment of criminal statutes targeting corporate directors who committed white-collar crimes. Moreover, as noted, the German criminal code has been revised repeatedly over the past three decades to broaden the reach of criminal statutes banning, for example, money laundering

German one. See William T. Pizzi \& Luca Marafioti, The New Italian Code of Criminal Procedure: The Difficulties of Building an Adversarial Trial System on a Civil Law Foundation, 17 YALE J. INT'L L. 1 (1992).

89. For a recent overview of the Siemens scandal, see, for example, Mike Esterl \& David Crawford, Suspicious Dealings Worth More Than Thought, Probe Finds: Dubious Transactions at Siemens Reach \$2-3 Billion, Four Times More Than Previous Tally, GLOBE \& MAIL, Sept. 27, 2007 , at B17.

90. For a thorough historical development of the regulation of corporations and the development of corporate law in European countries and the United States, see Beth Ahlering \& Simon Deakin, Labor Regulation, Corporate Governance, and Legal Origin: A Case of Institutional Complementarity?, 41 LAW \& SOC'Y REV. 865 (2007). Cf. Martin Lipton, Corporate Governance in the Age of Finance Corporatism, 136 U. PA. L. REv. 1, 3 (1987) (" $[\mathrm{C}]$ orporate governance ... cannot be created from abstract formalisms or idealized models of the corporation. Rather, to be effective, the corporate governance reforms proposed by this generation must address the problems and relationships that characterize the present state of [a nation's] corporatism."). 
and fraudulent misstatements. ${ }^{91}$ Such developments strongly suggest an acute awareness of the growing risk of corporate malfeasance and would seem to belie any suggestion that European countries genuinely felt immune from the risks corporate crime posed.

\section{The "European Efficiency" Account}

One final argument worth noting - what I term the "European Efficiency" account - relies on the vast body of work suggesting that criminal sanctions for corporations are inefficient because they do little either to dissuade corporate malfeasance or to encourage companies to take preventive measures, and that civil sanctions and administrative regulation can be more readily calibrated to impose punishments likely to serve both punitive and deterrent ends. ${ }^{92}$

While such work has not been explicitly raised in the comparative debate, it can readily and logically be extended: such an account would hold that European systems forego punitive criminal sanctions in favor of more efficient civil and administrative regulations. Moreover, such an argument might explain why corporate crime in Europe, while certainly present and of concern, has not taken on quite the same scope or severity as it has in the United States: by creating a more efficient system, the Europeans have effectively shifted compliance to corporations themselves, without impeding the progress or creation of internal compliance systems through the enactment of inefficient criminal penalties.

The problems with the efficiency model, however, are twofold. First, no European government has explicitly justified its civil or administrative system on the grounds that such a system is more efficient than a criminal one. ${ }^{93}$ Second, and perhaps more important, the efficiency argument fails to explain why the United States -in light of the virtually undisputed ${ }^{94}$ scholarly

91. See Roland Hefendehl, Enron, WorldCom, and the Consequences: Business Criminal Law Between Doctrinal Requirements and the Hopes of Crime Policy, 8 Buff. CrIM. L. Rev. 51, 60 (2004).

92. See, e.g., id. at 74 (citing studies establishing that "civil law reforms-especially that of the law of associations - have better prospects of success [in controlling corporate behavior] than does substantive or procedural criminal law"); Parker, supra note 12, at 390 .

93. See generally Beale \& Safwat, supra note 6 (surveying recent changes in France and Italy among other countries).

94. There are a few scholars, however, who have suggested that the rise of the criminal law was a response to " $[\tau]$ he failure of the civil regulatory scheme ... to prevent or even to report unlawful conduct in corporate offices" and that, as a result, "federal prosecutor[s] [have become] the main vindicator of the public interest in lawful business behavior." Moohr, supra note 3, at 165-66. 
criticism of corporate criminal liability as inefficient-continues to impose criminal sanctions on corporations, and in fact, does so with increasing frequency for a growing number of crimes. Put differently, if the efficiency account is correct, why does the United States - in the face of this undisputed criticism - continue unabated in its criminal punishment of corporations?

\section{Summary}

It is that last question that motivates this Note: assuming both the United States and Germany take seriously the threat of corporate malfeasance, and knowing that both have significant regulatory systems in place along with criminal liability for individual officers and agents who engage in illegal conduct, what purpose - or perhaps, more accurately - what additional purpose does corporate criminal liability serve in the United States? ${ }^{95}$

In Part II, this Note tackles that question directly. It looks beyond corporate criminal liability to each country's criminal justice system more broadly and suggests that corporate criminal liability in the United States has not grown because of its power to regulate corporate conduct or punish corporate malfeasance. Instead, the threat of corporate criminal sanctions has blossomed as a tool of American prosecutors, one that allows them to better navigate the unique perils of American criminal procedure and to pursue individual wrongdoers much as their German counterparts do.

\section{THE COMPARATIVE CRIMINAL PROCEDURE ACCOUNT}

While the above discussion highlighted differences in the substantive criminal law, the German and American criminal justice systems can far more readily be distinguished based on their vastly different approaches to criminal procedure. The American system, built on the common law model, is adversarial, while the German system has its roots in the Continental inquisitorial model. The differences between those two approaches permeate the justice systems in both countries: the traditional inquisitorial system is dominated by the judge and the court and focuses on finding the "truth." Lawyers play a relatively minor role, rules of procedure are simple and

95. Indeed, as noted above, criminal sanctions are not considered an efficient response to corporate misconduct. See, e.g., John C. Coffee, Jr., "No Soul To Damn: No Body To Kick": An Unscandalized Inquiry into the Problem of Corporate Punishment, $79 \mathrm{MICH}$. L. REv. 386, 386-87 \& n.4 (1981); Daniel R. Fischel \& Alan O. Sykes, Corporate Crime, 25 J. LeGAL STUD. $319,321(1996)$. 
straightforward, and the court gathers evidence and arrives at a conclusion. The adversarial system, by contrast, puts lawyers front and center, making the trial less a truth-seeking endeavor and more of a contest, one with complex and rigid rules that the most talented contestants and their lawyers can readily manipulate to their side's advantage. ${ }^{96}$ Put differently, or perhaps more generally, the German justice system might be compared to the process of solving a puzzle, with the judge driving a truth-seeking inquiry, one interested primarily. in determining the correct answer. The American system, by contrast, is more readily analogized to a chess match - one in which lawyers, as adversaries, play the crucial roles in advocating for victory.

Those differences are exacerbated in the context of the criminal justice system and white-collar prosecutions in particular. White-collar charges often involve the most complex factual predicates and nuanced understandings of guilt: quite literally, there is no "smoking gun," and establishing guilt often requires prosecutors to pore over millions of documents to prove what the defendant knew, when he knew it, what his intent was, and why he acted or failed to act. ${ }^{97}$ Moreover, white-collar defendants are often able to hire teams of the best lawyers to advocate on their behalf. Where the goal of the trial is truth seeking, those realities may slow, but not impede, the march to justice. In the context of the adversarial system and its chess-match mentality, however, the difficulties of pursuing white-collar criminal defendants become far more significant obstacles to the pursuit of justice.

It is in the face of these difficulties that the discrepancies between the adversarial and inquisitorial systems have allowed the very different approaches to corporate crime to blossom. Or so I shall argue. In particular, there are two significant types of differences between the American, adversarial system on the one hand, and the German, inquisitorial system on the other that, taken in tandem, help to explain why corporations are targets of criminal charges in the United States but not in Germany. The first difference is evidentiary. The inquisitorial system, with its focus on truth seeking, is

96. An enormous body of scholarship has explored the differences between the inquisitorial and adversarial system, including in the context of criminal law. For overviews of the two systems generally, see, for example, MIRJAN R. DAMAŠKA, EVIDENCE LAW ADRIFT (1997); Markus D. Dubber, Criminal Law in Comparative Context, 56 J. LeGAL EduC. 433 (2006); and Gerard E. Lynch, Our Administrative System of Criminal Justice, 66 FordHAM L. REv. 2117, 2117-41 (1998).

97. For an excellent discussion of the difficulties of prosecuting and defending white-collar criminal charges in the American system, see KenNeth MANN, Defending White-Collar CRIME: A PORTRAIT OF ATTORNEYS AT WORK (1985). 
generally guided by the principle of "freedom of proof,"98 one that both facilitates the investigatory phase and ensures that as much information as possible actually makes it into court. ${ }^{99}$ The adversarial system, by contrast, often stymies the prosecutor in his attempt to investigate and to introduce evidence, giving defense counsel tools for objecting to its admission on grounds that simply would not exist in an inquisitorial court.

The second major type of difference between the two systems falls into what I will broadly term "prosecutorial powers." The distinctions here are critical: American prosecutors possess great discretion to bring charges in the first place, to determine what charges to bring, and perhaps most important of all, to negotiate plea bargains. German prosecutors, by contrast, are far more limited public servants, ones given almost no discretion and overseen far more closely by judges and courts. German prosecutors are required to bring charges if the facts support doing so, are limited to charging only the specific offense provided for by statute, and have very limited power to negotiate deals with defendants. ${ }^{100}$

When combined, the above differences between the two criminal systems produce the following divergent results: American prosecutors leverage the powers they possess over corporations, as defendants, to facilitate the prosecution of individual directors otherwise protected by American criminal procedure. German prosecutors, by contrast, have neither the power nor, critically, the need to engage in such indirect tactics, since German criminal procedure facilitates, rather than hinders, the prosecution of individual wrongdoers.

In other words, American corporate criminal liability can and should be seen as part of an effort by American prosecutors to pursue individual corporate directors - the same directors who would be targeted by the German criminal system. Reaching that conclusion requires further elaboration of the differences, and an understanding of how those differences play out in the context of actual investigations and prosecutions in both countries.

\section{A. The Evidentiary Differences}

While much is often made of the rather arcane set of American evidentiary rules, which have no place in a truth-seeking, inquisitorial system, the

98. See J.R. Spencer, Evidence, in European Criminal Procedures 594, 602 (Mireille Delmas-Marty \& J.R. Spencer eds., 1995).

99. See infra notes 104-113 and accompanying text; see also DAMAŠKA, supra note 96 , at 15. 100. See infra notes 161-171 and accompanying text. 
evidentiary burdens placed on American prosecutors begin well before the trial where those rules apply. Indeed, from the initial complaint through the investigation, American prosecutors are hampered by rules and restrictionswhether statutory or constitutional-that are foreign to the inquisitorial system.

In the American system, investigations and the gathering of evidence are handled primarily by the police, who are overseen and directed by the prosecutor. Judges may be consulted if a warrant is needed or if there is a question of law involved, but they otherwise play no direct role in the investigation. ${ }^{101}$ Because the investigation is directed by the prosecutor, it, like the ensuing trial, takes the adversarial form. As a result, American defendants have no obligation to talk to or cooperate with the investigators - that is, with their adversaries - and if they do, they have a well-established and protected right to have counsel present at any such meetings. For indigent defendants relying upon court-appointed counsel, that protection may not seem terribly significant. But white-collar criminal defendants are rarely indigent, and for such defendants, the right to have counsel present during the investigatory stage is effectively a call to arms: corporate leaders under investigation routinely hire teams of attorneys from the best firms in the country to work tirelessly to stave off a criminal indictment. ${ }^{102}$

For purposes of this discussion, it is also worth noting just who is paying for that squadron of lawyers, whose fees, over the course of even a small investigation, can run into the millions of dollars. By contract or company custom, most mid- and high-level American employees have a right to corporate indemnification - that is, to have their employers pay their legal fees for any criminal investigation relating to their work conduct. ${ }^{103}$ There is little doubt that without indemnification agreements, even the best-paid corporate executives would be unable to afford the type of legal protection deep corporate pockets can provide. ${ }^{104}$ From the prosecutor's perspective, therefore, corporations play a crucial role in helping their employees combat, if not evade, criminal investigation and prosecution.

101. For a discussion of the American investigatory system in a comparative context, see Yue Ma, A Comparative View of Judicial Supervision of Prosecutorial Discretion, 44 CRIM. L. BULL., Jan.Feb. 2008, at 31.

102. See MANN, supra note 97 .

103. See generally 3A William MeAde Fletcher et al., Fletcher Cyclopedia of THE LAW OF Private CORPORATIONS $\$ 1344.10$, at $556-66$ (perm. ed., rev. vol. 2002) (discussing the history and modern practice of corporate indemnification agreements).

104. See United States v. Stein, 435 F. Supp. 2d 330, 371 (S.D.N.Y. 2006). 
The role those squadrons of attorneys play-and the adversarial nature of their relationship with the prosecutor - then becomes critical to the process of investigating and gathering evidence. Defense attorneys have a right to oversee the execution of search warrants and subpoenas and to contest the admissibility of each piece of evidence thereby obtained. Assisting them in that process is the aforementioned set of arcane American evidentiary rules, adopted from common law and preserved despite decades, if not centuries, of scholarly criticism. ${ }^{105}$ Those include, for example, prohibitions on hearsay ${ }^{106}$ or "bad character" evidence, ${ }^{107}$ evidence that might be particularly relevant to helping a jury determine whether a corporate executive knew - or did not know - what exactly he was doing.

Perhaps the most crucial evidentiary rule in this context is that of corporate attorney-client privilege. In the United States, much as corporations can be "persons" for the sake of the criminal code, they are "persons" for the purposes of privilege laws. A judicially developed doctrine, the corporate attorney-client privilege, while once narrow, has greatly expanded since its inception. ${ }^{108}$ Today, it covers virtually anything discussed between in-house corporate counsel and any company employee, provided that the communication pertains to the employee's official responsibilities and can be characterized as related to the attorney's representation of the company. ${ }^{109}$ The corporate privilege, thus,

105. See, e.g., Roger C. Park \& Michael J. Saks, Evidence Scholarship Reconsidered: Results of the Interdisciplinary Turn, 47 B.C. L. REV. 949 (2006) (collecting scholarship critiquing the American evidentiary rules); see also DAMAŠKA, supra note 96 , at 7-25 (criticizing the development of American evidentiary rules).

106. See FED. R. Evid. 801-807 (generally excluding hearsay with certain, narrow exceptions). See generally 2 CHARLes T. MCCORMICK, MCCORMICK ON EVIDENCE $\$ \$ 244-53$, at 122-77 (Kenneth S. Broun ed., 6th ed. 2006) (discussing the hearsay exception).

107. See FED. R. Evid. 404(a) (excluding generally any "evidence of a person's character or a trait of character"); FED. R. EVID. 404(b) (excluding mention of any prior convictions). See generally 1 MCCORMICK, supra note 106, $\$ 190$, at 752-68 (discussing the bad character evidence exception).

108. The corporate attorney-client privilege was first recognized by the Supreme Court in United States v. Louisville \& Nashville Railroad Co., 236 U.S. 318 (1915), and was, for some time, limited to communications between attorneys and the corporation's top management or "control group." That rule has since been abandoned and the privilege greatly expanded. See infra note 109 and accompanying text.

109. See Upjohn Co. v. United States, 449 U.S. 383 (1981). In Upjohn, the Court noted four factors that compelled its finding that the privilege attached, although it made clear the four were not necessary to such a finding in all cases. These factors were as follows: (1) the communications were made to corporate attorneys to facilitate their provision of legal advice to the company; (2) the communications were made at the request of the employee's superiors; (3) the communications concerned matters within the scope of the employee's corporate duties; and (4) the communications were treated as confidential, attorney-client 
can shield as protected anything from legal advice given to senior management to general statements of legal advice or policy distributed widely throughout the corporation. ${ }^{110}$ Much like the individual privilege, the corporate attorneyclient privilege also protects attorney work product-including any internal investigations or inquiries into the underlying conduct made by corporate counsel. ${ }^{111}$

The privilege is held by the company, not any individual employee, which means that the corporation has the authority to invoke it or to waive it. ${ }^{112}$ But because of its breadth, once invoked, it can and does block American prosecutors from obtaining all sorts of internal company records and correspondence - often the type of information necessary to establish what the defendant knew or did not know when authorizing the illegal behavior in question. $^{113}$

Finally, it is worth noting that much as the corporate lawyer is said to have an attorney-client relationship with all corporate employees, the in-house lawyer is also said to represent all such employees. Thus, when a corporation comes under investigation, it can and will claim that all of its employees are represented by counsel, thereby making it impossible for law enforcement officers or prosecutors to contact any individual employees without first going through the corporation's counsel. ${ }^{114}$ As a result, cultivating sources within a company and finding whistleblowers becomes much more difficult.

communications at the time they were made. Id. at 394-95. For more on the corporate attorney-client privilege, its history, and its current scope, see CHRISTOPHER B. MUELLER \& LAIRD C. KirKPATRICK, EVIDENCE $\$$ 5.16, at 336-46 (3d ed. 2003).

110. See, e.g., James Julian, Inc. v. Raytheon Co., 93 F.R.D. 138 (D. Del. 1982) (holding that the availability of legal opinion memoranda to much of the corporation did not destroy the privilege).

m. See, e.g., Upjohn, 449 U.S. 383 (finding that an internal investigation of potential tax fraud conducted by the corporation's in-house attorney was privileged and thus could not be obtained by IRS investigators).

112. See Commodity Futures Trading Comm'n v. Weintraub, 471 U.S. 343, 348 (1985) (" $[F]$ or solvent corporations, the power to waive the corporate attorney-client privilege rests with the corporation's management and is normally exercised by its officers and directors.").

113. See also Daniel Richman, Decisions About Coercion: The Corporate Attorney-Client Privilege Waiver Problem, 57 DEPAUL L. REV. 295, 299-300 (2008) (discussing the type of information sought and obtained through waiver).

114. See also James William Coleman, The Criminal Elite: Understanding White Collar CRIME 172-73 (5th ed. 2002) (discussing the "delaying game" whereby corporate counsel use the privilege as leverage to secure a deal for the corporation, threatening otherwise to thwart the investigation of individual wrongdoers). See generally The Thompson Memorandum's Effect on the Right to Counsel in Corporate Investigations: Hearing Before the S. Comm. on the Judiciary, 109th Cong. 117-18 (2006) (statement of Paul J. McNulty, Deputy Att'y Gen. of 
By contrast, the German inquisitorial system is guided by the Prinzip der materiellen Wahrheit, or the principle of factual truth, a principle that guides both the investigation and the ultimate trial. ${ }^{115}$ Indeed, unlike an American investigation, which is adversarial in nature, the court in Germany oversees investigations, rendering them a critical component of the search for the truth. While prosecutors and police still play the primary role in the day-to-day investigation, the process is not adversarial. Moreover, the judge, not the prosecutor, has the final say on whether enough evidence has been gathered, and a judge unsatisfied with the evidence adduced at trial can direct police to investigate further or to produce certain information. ${ }^{116}$

At the investigatory stage ${ }^{117}$ prosecutors oversee the gathering of relevant information that will then be presented to the judge at trial. Because prosecutors are as much officers of the justice system as they are "adversaries," they are given the authority to engage in what Americans would view as coercive tactics. Most notably, German prosecutors can require the defendant to attend an interview with investigators. ${ }^{118}$ While the suspect must be informed of several rights, including the right to remain silent, unlike in the American system, the German defendant has no right to have an attorney present at the initial interrogation, let alone a team of attorneys. ${ }^{119}$ Indeed, German prosecutors or judges can exclude a defendant's lawyer from the interrogation if the lawyer's presence would be a "danger to the success of the investigation." 120

Moreover, even at subsequent proceedings where a German defendant is entitled to have an attorney present, he is limited to three lawyers, total. ${ }^{121}$ And

the United States) (discussing how corporate counsel can use privilege to block criminal investigations if they so choose).

115. Rodolphe Juy-Birmann, The German System, in European Criminal Procedures, supra note 98 , at 292, 309 .

116. See id.

117. The German criminal justice system is generally divided into three phases: the preparatory stage (Vorverfahren), the intermediate phase (Zwischenverfahren), and the trial (Hauptverfahren). See id. at 312-15. This Note uses the terms "investigatory stage" and "preparatory stage" interchangeably.

118. Strafprozeßordnung [StPO] [Code of Criminal Procedure] Feb. 1, 1877, Reichsgesetzblatt [RGBl.] 253, as amended, \$163a, 9 III, sentence 1.

119. Juy-Birmann, supra note 115 , at 320 .

120. Id. at 304 (quoting Strafprozeßordnung [StPO] [Code of Criminal Procedure] Feb. 1, 1877, Reichsgesetzblatt [RGBI.] 253, as amended, $\$ 168 \mathrm{c}$, $9 \mathrm{~V}$, sentence 2).

121. See Christian Fahl, The Guarantee of Defence Counsel and the Exclusionary Rules on Evidence in Criminal Proceedings in Germany, 8 GERMAN L.J. 1053, 1053 (2007) (quoting 
the German defendant is far more likely to pay for those attorneysindemnification agreements, while increasingly popular in the European Union, have never been as prevalent as they are in the United States. In Germany in particular, indemnification agreements remain an "exceptional practice." ${ }^{122}$ As a result, white-collar German defendants are unable-for both legal and financial reasons - to assemble the types of legal "dream teams" American executives so frequently rely on to fend off criminal prosecution.

None of this is to suggest that the German system mistreats defendants or denies them all forms of protection. To the contrary, the entire German system operates on the principle that basic human dignity must always be preserved. ${ }^{123}$ But despite providing for that standard, the German system also preserves the search for the truth, eschewing the type of prophylactic rules and procedural formalism that the United States imposes.

This approach permeates Germany's evidentiary rules. Germany, like most inquisitorial systems, favors the principle of, as the French term it, liberté des preuves-liberty of proof-which is to say that evidence is presumptively admissible. ${ }^{124}$ In Germany, evidence is said to be "free" - Freibeweis ${ }^{125}$ - and the role and responsibility of all parties appearing before the court is to provide the relevant information to the judge so that he can reach the factually correct result. In more concrete, comparative terms, this means that many of the rules that block the admission of evidence in the American system are not nearly as significant in the German one: hearsay is generally admissible, for example, as is evidence of prior bad acts or "bad character" evidence. ${ }^{126}$

Perhaps most important to my argument is the fact that Germans do not embrace the same form of broad exclusionary rule loathed by American prosecutors and revered by American criminal defense lawyers. In the German system, like the American one, evidence may be excluded if it was improperly or illegally obtained. Unlike the American system, however, the German criminal code defines "improper" or "illegal" methods to be those that undermine the credibility of the evidence itself-if, for example, the police used torture or took advantage of severe fatigue or mental handicap, any evidence

Strafprozeßordnung [StPO] [Code of Criminal Procedure] Feb. 1, 1877, Reichsgesetzblatt [RGBI.] 253, as amended, $\$ 137,9 \mathrm{I}$, sentence 2).

122. See Brian R. Cheffins \& Bernard S. Black, Outside Director Liability Across Countries, 84 TEX. L. REV. 1385, 1429 (2006) ("In Germany ... indemnification of directors is not explicitly addressed by company law and has traditionally been an exceptional practice.").

123. See Spencer, supra note 98 , at 607 .

124. Id. at 602 .

125. Juy-Birmann, supra note 115 , at 325 .

126. See Spencer, supra note 98, at 616-19. 
thereby obtained may be excluded. ${ }^{127}$ Judges may also exclude evidence that violates the defendant's allgemeines Personlichkeitsrecht, or "universal right of human personality." 128 Such evidence tends to include that which the court feels the police should not have obtained in the first place-personal diaries of witnesses, for example, or unauthorized tape recordings of private conversations. ${ }^{129}$

Germany otherwise has no blanket rule that evidence obtained in violation of criminal procedures automatically need be excluded. ${ }^{130}$ Evidence is certainly not excluded to deter police misconduct, unlike in the United States where such deterrence is a primary justification for, and explanation of, the American exclusionary rule. ${ }^{131}$ As one scholar noted, "Although it does not make much sense that there are rules governing the collection of evidence that may be disobeyed without consequences, this is the predominant opinion in Germany among the courts and in books on criminal law. The courts fear that otherwise too much evidence will be lost." ${ }^{132}$ Not surprisingly, as a result, the total amount of evidence excluded by a German court would pale in comparison to that deemed excludable in an American one. ${ }^{133}$

But in the context of white-collar crime, the evidentiary rule-and the difference-of greatest impact is the corporate attorney-client privilege. Here, the differences are stark: while in America, any conversation between an employee and an in-house lawyer can be privileged, in Germany the privilege is far more limited. Like most European countries, Germany views in-house lawyers as fundamentally different from the rest of the bar. In France, for instance, in-house lawyers have no attorney-client privilege because they are not deemed sufficiently independent to warrant such protection. ${ }^{134}$ German law is only slightly more protective: in-house lawyers are entitled to the protection of the privilege provided that they maintain separate offices, to which they

127. See id. at 607 (describing the law on Beweisverwertungsverbote or "prohibitions on use of evidence" as codified at Strafprozeßordnung [StPO] [Code of Criminal Procedure] Feb. 1, 1877, Reichsgesetzblatt [RGBI.] 253, as amended, $\$ 136 a$ ).

128. Id. at 607 n. 46 .

129. Id.

130. See Fahl, supra note 121, at 1061.

131. Id.

132. Id. (emphasis added) (collecting cases demonstrating this attitude on the part of German courts).

133. See Spencer, supra note 98 , at $607-08$ (discussing the more limited exclusion of evidence in Germany).

134. Joseph Pratt, The Parameters of the Attorney-Client Privilege for In-House Counsel at the International Level, 20 NW. J. INT'L L. \& BUS. 145, 166 (1999). 
have sole access, and that they answer to a general counsel who acts in his independent capacity as an attorney. ${ }^{135}$ More important, under German law, even that limited privilege applies only to records or documents possessed by the lawyer and not to anything held by the defendant. Therefore, when German investigators search the defendant's office, the thousands of documents they find-documents that would be presumptively privileged in the United States - are presumptively admissible in Germany. ${ }^{136}$

Taken as a whole, these rules make it notably, if not significantly, easier for German prosecutors to amass the sort of information they would need to prosecute individual officers or agents of a corporation believed to be engaged in wrongdoing. ${ }^{137}$ Moreover, as noted, where prosecutors fail to amass such evidence on their own, judges can and will use the trial itself as an opportunity to ask questions, to demand further information, and ultimately to determine what occurred. ${ }^{138}$

American prosecutors, of course, are not powerless in the face of these unique evidentiary burdens. But their powers are very different, and, thus, their use of those powers in the context of otherwise similar white-collar prosecutions creates a very different result.

\section{B. Prosecutorial Powers}

As a preliminary observation, it is worth noting that American prosecutors are American lawyers. As such, they are by nature adversarial, which is to say, competitive. Far from being neutral officers of the court, American prosecutors have the responsibility not only to present straightforward facts to a court, but also to advocate for their version of those facts. And while no self-respecting prosecutor would deny that truth seeking is at the heart of his work, ${ }^{139}$ American prosecutors, like all American lawyers, play to win. Prosecutors are

135. See id. at 167.

136. Id. at 161-62.

137. Cf. Moohr, supra note 3, at 200 (noting that the inquisitorial system "avoids or, more specifically, neutralizes" the problem of "the secrecy with which white collar crimes are committed").

138. See Denis Salas, The Role of the Judge, in European Criminal Procedures, supra note 98, at 488,489 .

139. Not surprisingly, prosecutors often view criminal defense attorneys as the source of abuses in the American system, abuses that prosecutors seek to curtail if not correct. As the standard saying goes, "Criminal defense lawyers play close to the line. Prosecutors play in the center of the court." Bruce A. Green, Why Should Prosecutors "Seek Justice"?, 26 FordHAM URB. L.J. 607, 617 (1999). 
invariably measured by how successful they are-their conviction rate. Particularly in state systems, where local prosecutors routinely stand election, conviction rates are invariably on the minds of even the most job-secure district attorneys. ${ }^{100}$ Moreover, as adversaries in an adversarial system, American prosecutors remain far more independent of the court and the judiciary than do their German counterparts. ${ }^{141}$ American prosecutors are located within a separate branch of government from judges, and, as a result, prosecutors make a wide variety of crucial choices that judges are not authorized to review, let alone reverse. This "prosecutorial discretion" includes the virtually unbridled authority $^{142}$ to decide when to bring charges against a defendant, what those charges should be, and when to offer the defendant a plea bargain to avoid an otherwise onerous penalty. ${ }^{143}$ Each of those sets of choices, in turn, deserves further attention. The discretion to charge means that a prosecutor faced with a sympathetic defendant can simply decide, based on his own instinct, not to proceed to trial. Perhaps of greater relevance here, the prosecutor can also choose not to press charges when the target of an investigation proves cooperative or offers to help the government investigate other potential criminals. Retaining discretion thus gives prosecutors virtually unreviewable power to determine when, and against whom, the criminal law will be enforced. ${ }^{144}$

The discretion to choose what charges to bring, in turn, contains two distinct but very important powers. First, the choice of what charges to bring,

140. Perhaps no case more publicly demonstrated this pressure and the manner in which it could affect criminal investigations than the recent Duke lacrosse team rape allegations. For a scathing account of that scandal and the role public pressure played on the district attorney, see Stuart TAylor, JR. \& KC Johnson, Until Proven InNOCENT (2007).

141. For an excellent recent article comparing American prosecutors to their counterparts in Germany, France, and Italy and discussing in particular the unique discretion and freedom enjoyed by American prosecutors, see Ma, supra note 101.

142. As a general rule, courts will only second-guess a prosecutor's exercise of this authority when a defendant claims that a prosecutor exercised his discretion in a discriminatory manner. Even there, the "presumption of regularity" applies to the prosecutor's conduct: "Because discretion is essential to the criminal justice process, we would demand exceptionally clear proof before we would infer that the discretion has been abused." McCleskey v. Kemp, 481 U.S. 279, 297 (1986).

143. See generally Laurie L. Levenson, Working Outside the Rules: The Undefined Responsibilities of Federal Prosecutors, 26 FORDHAM URB. L.J. 553 (1999) (discussing the series of powers prosecutors exercise when operating "outside the rules" or beyond the reach of formal legal restraint, including making investigatory, charging, and plea-bargaining decisions).

144. See James Vorenberg, Decent Restraint of Prosecutorial Power, 94 HaRv. L. ReV. 1521 (1981) (providing a theoretical and normative critique of the role of prosecutorial discretion in the American justice system). 
when coupled with a complex statutory framework that tends to overcriminalize, ${ }^{145}$ gives prosecutors the ability to charge a defendant with multiple counts arising from the same underlying conduct, and, as a result, to impose additional pressure on them to plead guilty. Martha Stewart, for example, was charged not only with obstruction of justice but also with securities fraud for the same underlying offense-lying about her involvement in and knowledge of the sale of ImClone stock. ${ }^{146}$

Second, the choice of what charges to bring - and the fact that such a choice is unreviewable-gives prosecutors a significant role in shaping the criminal code. Statutes like the RICO Act ${ }^{147}$ or the mail and wire fraud statutes ${ }^{148}$ contain broad prohibitions and vague language that has been manipulated by prosecutors in attempts to punish conduct that might not otherwise neatly fit into the federal criminal code. The wire fraud statute, for example, has been used to prosecute a man who impersonated a talent scout to score dates with models. ${ }^{149}$ The Hobbs Act, a federal robbery statute ostensibly targeting bank robberies and other major larcenies, ${ }^{150}$ was written so broadly that, as one commentator observed, it "seems literally to apply to the robbery of a candy store by a local hoodlum." 151

This prosecutorial power to shape the criminal code is critical in this context. As noted in Part I, many criminal statutes do not contain explicit provisions for corporate or entity liability. Nevertheless, prosecutors have applied them to corporate behavior by arguing that the criminal code covers all "persons," and that the U.S. Code generally defines "person" to include a corporation or an organization. ${ }^{152}$ Of course, Congress has not yet stepped in to

145. As used in this context, the term "overcriminalize" speaks both to the legislative tendency to make criminal what should not be, and the tendency to pass multiple laws covering similar, if not identical, conduct. For a greater discussion of both tendencies in the American system, see, for example, Erik Luna, The Overcriminalization Phenomenon, 54 AM. U. L. REV. 703 (2005). See also Moohr, supra note 3, at 181 ("The depth of the federal criminal lawduplicative statutes that apply to similar conduct-increases the prosecutorial power ... by giving prosecutors a plethora of offenses from which to choose.").

146. See Geraldine Szott Moohr, What the Martha Stewart Case Tells Us About White Collar Criminal Law, 43 Hous. L. REV. 591 (2006) (providing an in-depth discussion of the exercise of prosecutorial discretion in the context of the prosecution of Martha Stewart).

147. 18 U.S.C. $\$ \$ 1961-1968$ (2000).

148. Id. $\$ \$ 1341-1343$.

149. See United States v. Altman, 901 F.2d 1161 (2d Cir. 1990).

150. 18 U.S.C. $\$ 1951$.

151. Peter W. Low, Federal Criminal Law 7 (2d ed. 2003).

152. See supra note 42 and accompanying text. 
overrule that interpretation by, for instance, revising the U.S. Code. But far more important, neither have the courts. ${ }^{153}$ In Germany, as discussed at greater length below, the judge plays an instrumental role in evaluating the charges brought and approving them as being "correct." In the United States, as Professor Geraldine Moohr has noted, the "pattern ... [of] prosecutors raising new interpretations and courts acceding to them ... leads to an incremental, but inexorable, expansion of the laws." 154

The final of the three discretionary powers worth discussing is the power to offer and negotiate plea bargains, a power which controls, if not coerces, defendants in a slightly less direct fashion. Plea bargains in the United States operate within a justice system in which sentences are exorbitant, at least from a comparative perspective, and even relatively minor crimes can lead to lifechanging prison time. ${ }^{155}$ Pleas offer a way of avoiding, or at least reducing, those sentences. As a result, in modern America, some ninety-four percent of criminal charges end in plea bargains without a jury ever being empaneled, let alone rendering a verdict. ${ }^{156}$

But in addition to forcing defendants to forego a trial, prosecutors obtain another power through the ability to negotiate pleas: American prosecutors can force defendants, as a condition of pleading guilty, to cooperate and to help authorities with other investigations. Most commonly, cooperation entails testimony against codefendants, testimony which helps prosecutors convict criminals who might otherwise evade the criminal justice system. The power to negotiate plea bargains, in other words, is not just a means for prosecutors to reduce their case load. Rather, plea bargaining gives prosecutors a critical tool for investigating and prosecuting other criminals. ${ }^{157}$ And while statistics are

153. See Moohr, supra note 3, at 181 (noting that, in the context of white-collar crime in particular, "[t] he combination of ambiguous conduct and broad, vague statutes enhances prosecutorial power by implicitly authorizing prosecutors to classify certain conduct as criminal").

154. Id. at 179. Some of the most noted scholars in the field have expressed similar thoughts. See, e.g., Dan M. Kahan, Is Chevron Relevant to Federal Criminal Law?, 110 HARv. L. REV. 469 (1996); Daniel C. Richman, Federal Criminal Law, Congressional Delegation, and Enforcement Discretion, 46 UCLA L. REV. 757 (1999); William J. Stuntz, The Pathological Politics of Criminal Law, 100 MICH. L. REV. 505 (2001).

155. See WHITMAN, supra note 11.

156. See Stephanos Bibas, Plea Bargaining Outside the Shadow of Trial, 117 HARV. L. REV. 2463, 2497 (2004) (citing U.S. Department of Justice statistics that between ninety-four and ninety-five percent of federal criminal defendants plead guilty).

157. See Stephen S. Trott, Dep't of Justice, The Successful Use of Informants and Criminals as Witnesses for the Prosecution in a Criminal Case, in PROSECUTION OF PUBLIC CORRUPTION 
difficult to come by, some have estimated that most criminal prosecutions that actually go to trial rely on cooperator testimony in some form. ${ }^{1{ }^{8} 8}$ Finally, it is worth reiterating that prosecutors not only have the power to make the above decisions, but they have the power to make them alone. An aggrieved victim, angered that charges were not filed, cannot sue to compel prosecution. ${ }^{159}$ The "local hoodlum" charged with violating the Hobbs Act cannot ask the judge to reduce the charges. ${ }^{160}$ Above all, a defendant facing the option between pleading guilty or going forward with a trial that would result in a death sentence will likely feel compelled to accept the deal.

German prosecutors-and the powers they exercise-look nothing like their American counterparts. German prosecutors are required by law to investigate all accusations brought to them. ${ }^{161}$ They are then bound by the "legality principle"-Legalitatsprinzip ${ }^{162}$-to press charges if the initial investigation turns up sufficient evidence to warrant proceeding. There is no significant discretion involved.

Indeed, the legality principle is a core component of the German system, and until 1975, it was virtually absolute. More recently, German law has relaxed the requirement under certain, limited circumstances, giving prosecutors a

CASES 115, 119-20 (1988) ("If a policy were adopted never to deal with criminals as prosecution witnesses, many important prosecutions could never make it to court.").

158. See id.; see also United States v. Singleton, 165 F.3d 1297, 1301 (1oth Cir. 1999) (en banc) (affirming the legality of offering more lenient plea bargains to cooperating witnesses in return for their testimony, while noting that " $[\mathrm{n}]$ o practice is more ingrained in our criminal justice system than the practice of the government calling a witness who is an accessory to the crime for which the defendant is charged and having that witness testify under a plea bargain that promises him a reduced sentence") (citations omitted).

159. See Inmates of Attica Corr. Facility v. Rockefeller, 477 F.2d 375 (2d Cir. 1973) (holding that a federal court lacked the authority to compel a prosecutor to bring charges against prison guards who allegedly assaulted the plaintiffs while in custody).

160. The only exception to this is where the defendant asserts that, as a matter of law, he cannot be guilty of the crime charged. Such challenges, which often invoke the rule of lenity - that is, that the meaning and scope of criminal laws should be read strictly and in the light most favorable to the defendant-are rarely successful, as judges almost always defer to prosecutors' and juries' views of what the law criminalizes. See MARKUS D. DUBBER \& MARK G. Kelman, AmERICAN Criminal LAW 123-44 (2005) (discussing rule of lenity challenges by defendants and American courts' increasing hostility toward them); Dan M. Kahan, Lenity and Federal Common Law Crimes, 1994 SuP. CT. REv. 345, 346 ("Judicial enforcement of lenity is notoriously sporadic and unpredictable.").

161. This is known as Grundsatz der Strafverfolgung durch den Staat or Offizialprinzip, and is codified at Strafprozeßordnung [StPO] [Code of Criminal Procedure] Feb. 1, 1877, Reichsgesetzblatt [RGBI.] 253, as amended, $\ 152$, q I. See also Juy-Birmann, supra note 115, at 308 (discussing the requirement imposed on German prosecutors to investigate).

162. Juy-Birmann, supra note 115 , at 338-39. 
modicum of discretion. But even then, the decision not to prosecute generally requires the approval of a presiding judge. ${ }^{163}$ Moreover, should the prosecutor decide not to press charges and should the presiding court sign off on that decision, the victim then has the right to effectively take over the prosecution by filing a Privatklage, or private complaint. ${ }^{164}$ Should charges be appropriate, German prosecutors also have far less control over what charges to bring for two reasons. First, the German system - like most Continental systems - leaves far less uncertainty in the criminal code and gives lawyers less room to push or mold the law through the type of "creative lawyering," practiced by American lawyers. ${ }^{165}$ The German prosecutor's role is not to choose among many possibilities, but to determine the "correct" charges to bring and then to file them in an indictment. Second, and perhaps more important, German prosecutors must then submit the charges to a judge who has the authority to alter the charges if he feels they do not adequately reflect the alleged conduct. ${ }^{166}$

German prosecutors also possess far less authority to offer or to negotiate plea bargains. In fact, until 1979, Germany was, as Professor John Langbein termed it, a "land without plea bargaining." 167 While more recent reforms have eased that rule, plea bargaining remains drastically more limited than it is in the United States. Today, the most common form of German plea bargaining

163. See, e.g., Strafprozeßordnung [StPO] [Code of Criminal Procedure] Feb. 1, 1877, Reichsgesetzblatt [RGBl.] 253, as amended, $\mathbb{S} 153 \mathrm{~b}$, ๆ I (allowing for charges to be dropped on the grounds that the sentence would be inappropriate, but only with consent of the court); id. $\$ 153$, ฯ I, sentence 1 (allowing for charges of minor importance to be dropped but only with the court's permission).

164. Juy-Birmann, supra note 115 , at 319.

165. Unlike the American system which allows for law to develop through application, most civil law countries require that the law develop solely through the development of the code. See generally John Henry Merryman, THE CIVIl LaW Tradition 34-36 (2d ed. 1985) (discussing differences between the development of law in civil law and common law countries); RUDOLPH B. SCHLESINGER ET AL., COMPARATIVE LAW 296-98 (5th ed. 1988) (discussing the roles of courts and legislatures in the development of law).

166. Strafprozeßordnung [StPO] [Code of Criminal Procedure] Feb. 1, 1877, Reichsgesetzblatt [RGBl.] 253, as amended, $\$ 165,91$, sentence 1 (giving judges the authority to substitute charges provided the new charges are based on conduct included in the initial accusation); see also Juy-Birmann, supra note 115, at 314; Jenia Iontcheva Turner, Judicial Participation in Plea Negotiations: A Comparative View, 54 AM. J. CoMP. L. 199, 215 (2006) (noting that German "[j]udges also have substantial control over the charges filed" including the authority to substitute, adjust, and even dismiss charges, and that, in that process, "judges can probe into the relevant facts on their own initiative, going beyond the investigative file compiled by the police and presented by the prosecution").

167. John H. Langbein, Land Without Plea Bargaining: How the Germans Do It, $78 \mathrm{MICH}$. L. Rev. 204 (1979). 
involves only low-level offenses for which the defendant promises to pay civil restitution or a fine in return for having the charges dropped. ${ }^{168}$ Germany is also currently developing a form of "sentencing bargaining"-a reduced sentence in return for the admission of guilt - that looks more akin to American plea bargaining but with one crucial distinction: in Germany, the entire process is overseen by a judge who will hear the defendant's confession, determine its validity, and then proceed to sentence appropriately. ${ }^{169}$

Moreover, it is worth noting that one of the key reasons plea bargaining has less relevance in the German system is that sentencing, far from being dictated by guidelines as it is in the United States, ${ }^{170}$ is left generally to the discretion of the judge. While most crimes in the German code will provide for a maximum penalty, judges are free to impose a punishment they feel most accurately reflects the defendant's culpability, the seriousness of his crime, the defendant's prior criminal history, and the like. ${ }^{171}$ German prosecutors, therefore, would be unable to do what their American counterparts canthreaten a particular (harsh) sentence and promise a far more lenient one in return for a plea.

\section{Finishing the Explanation: How the American System Works in Practice}

Thus far, this Note has described differences between the American and German systems. It has attempted to establish how the American system, on the one hand, hamstrings prosecutors pursuing individual white-collar defendants, but on the other hand, gives them enormous power over potential defendants and the targets of investigations. Completing the argument-that is, showing how the prominence of corporate criminal liability in the United States has been driven by prosecutors responding to those evidentiary burdens-requires considering the two aspects of the American system together and analyzing how prosecutors have used the above described powers

168. See Turner, supra note 166 , at 218 -19 (discussing the application of section 153 (a) of the code and how it is limited to crimes punishable by one year or less in prison).

169. See id. at 219-21.

170. More recent Supreme Court opinions have rendered the sentencing guidelines as nonbinding, giving judges greater discretion in sentencing defendants. Nevertheless, the guidelines play a very important role in American sentencing, and large departures from the sentencing guidelines remain the exception to the rule. See Graham C. Mullen \& J.P. Davis, Mandatory Guidelines: The Oxymoronic State of Sentencing After United States v. Booker, ${ }_{11} \mathrm{U}$. RICH. L. REV. 625 (2007).

171. Turner, supra note 166, at 215-16 (collecting statutes and providing interviews with German judges discussing the sentencing process). 
against corporations to overcome evidentiary burdens they face in prosecuting individuals.

In particular, the recent American prosecutorial practice of using cooperation agreements-generally in the form of "deferred prosecution agreements" - and the terms and conditions American prosecutors have attached to those agreements shed considerable light on the validity of the argument advanced thus far.

\section{The Thompson Memorandum and the Use of "Deferred Prosecution} Agreements"

In the years since Enron, pursuit of corporate malfeasance has increased significantly, and a large number of corporations have come under investigation. Yet virtually none of those corporations has actually gone to trial. With very few exceptions, every such corporation has been offered a dealoften a deferred prosecution agreement or "DPA" - in return for the company's cooperation with the government's investigation. ${ }^{172}$ Corporations, well aware of the harm that an indictment, let alone a conviction, would cause, have eagerly accepted such deals. As one pair of scholars recently noted, "In the post-Enron world, it is the rare corporation that will risk indictment . . . let alone a trial.... Knowing this, the government has virtually unfettered discretion to exact a deferred prosecution agreement from a corporation ...."173

A DPA requires a defendant to meet certain conditions in return for a prosecutor's promise to defer any prosecution-and ultimately to drop charges - provided the conditions are met. ${ }^{174}$ Because the authority to bring charges or to offer a deal rests exclusively with the prosecutor, he has virtually complete control over negotiating the terms of a DPA. And in the context of DPAs offered to corporations, the terms imposed by prosecutors are very telling: to "cooperate," corporations are generally required to take a series of

172. See Eric Lichtblau, In Justice Shift, Corporate Deals Replace Trials, N.Y. TIMES, Apr. 9, 2008, at A1.

173. Weissmann \& Newman, supra note 4 , at 414.

174. For an excellent overview of deferred prosecution agreements authored by two former federal prosecutors, see Michael R. Sklaire \& Joshua G. Berman, Deferred Prosecution Agreements: What is the Cost of Staying in Business? LEGAL OpINION LETTER (Wash. Legal Found., Washington D.C.), June 3, 2005, available at http://www.wlf.org/upload/ 060305 LOLSklaire.pdf. 
steps aimed primarily at facilitating the investigation of those individual employees accused of misconduct. ${ }^{175}$

The terms and conditions prosecutors can, and indeed must, consider in determining whether to offer a corporation a DPA were, until recently, set out in the Thompson Memorandum, which more generally provided prosecutors with a set of policies developed at the Department of Justice to guide the investigation and prosecution of corporations. ${ }^{176}$ Noting that a prosecutor was likely to encounter "obstacles" in pursuing individual defendants, including difficulty "determin[ing] which individual took which action," the Thompson Memo instructed prosecutors that "a corporation's cooperation may be critical in identifying the culprits and locating relevant evidence." 177

With that goal in mind-identifying and pursuing individual "culprits"the Thompson Memo therefore authorized prosecutors to require "cooperating" corporations (1) to waive the corporation's attorney-client privilege and then produce any and all documents and records prosecutors seek in their investigation of individual employees; ${ }^{178}(2)$ to provide assistance in discovery by instigating an internal investigation of the misconduct, interviewing potentially culpable individuals, and hand-delivering relevant documents rather than forcing prosecutors to sift through the millions of documents themselves; ${ }^{179}$ (3) to terminate indemnification of individual employees under investigation, thereby forcing them to retain - and pay for-

175. See Kern Griffin, supra note 1, at 329 (noting the increased "partnering" of the government via DPAs "coincides with a shift to retail prosecution of individuals" and concluding that corporations were using individual employees as "currency to purchase corporate deferral [agreements]").

176. Memorandum from Larry D. Thompson, Deputy Att'y Gen., to Heads of Dep't Components and U.S. Att'ys, (Jan. 20, 2003) [hereinafter Thompson Memo], available at http://www.usdoj.gov/dag/cftf/business_organizations.pdf. The Thompson Memo was revised in December 2006 and replaced by the McNulty Memo. See supra note 17.

177. Thompson Memo, supra note 176 , at 6 .

178. Id. ("In gauging the extent of the corporation's cooperation, the prosecutor may consider the corporation's willingness to identify the culprits within the corporation, including senior executives; to make witnesses available; to disclose the complete results of its internal investigation; and to waive attorney-client and work product protection."); see id. at 7 ("One factor the prosecutor may weigh in assessing the adequacy of a corporation's cooperation is the completeness of its disclosure including, if necessary, a waiver of the attorney-client and work product protections .... Such waivers permit the government to obtain statements of possible witnesses, subjects, and targets ....").

179. See id. (noting that the DOJ "encourages corporations [seeking to cooperate] ... to conduct internal investigations and to disclose their findings to the appropriate authorities"). 
their own lawyers $;^{180}$ and (4) to cease any other assistance to individual employees under investigation, by terminating them immediately, barring them from accessing their own offices or records or from speaking with other employees. ${ }^{181}$

Of course, each of the above conditions could be considered relevant to evaluating the corporation's misconduct as an entity. But of more theoretical importance and practical significance, each of the above conditions greatly facilitates efforts to investigate individual employees, and a number of the above conditions make it far more difficult for those individuals to defend themselves from criminal prosecution. Waiver of the privilege, for example, allows prosecutors to overcome one of the more critical evidentiary hurdles to investigating individuals, and termination of indemnification often precludes individual employees from retaining large legal defense teams that might further hinder investigation and prosecution. Indeed, as the Thompson Memo stated explicitly, "indicting corporations for wrongdoing enables the government to ... prevent, discover, and punish [individual] white collar crime." 182

That criminal prosecution is meant to help prosecutors pursue individual defendants-rather than to accurately address a corporation's criminal culpability-is further evinced by the factors prosecutors do not need to consider in determining whether or not to press charges against a company. Under the directives of the Thompson Memo and its more recent incarnations, ${ }^{183}$ federal prosecutors need not give determinative weight to the

180. Id. at 7-8 (" $[\mathrm{A}]$ corporation's promise of support to culpable employees and agents, ... through the advancing of attorneys fees ... may be considered by the prosecutor in weighing the extent and value of a corporation's cooperation.").

181. Id. at 7 ("Another factor to be weighed by the prosecutor is whether the corporation appears to be protecting its culpable employees and agents.").

182. Id. at 1 .

183. In response to considerable criticism, the Department of Justice has revised and largely abandoned the Thompson Memo as Department practice. While the McNulty Memo, which replaced the Thompson Memo, imposed some limits on when prosecutors could make each of the demands highlighted in this discussion - notably, when prosecutors could demand that a company waive its attorney-client privilege-it nonetheless reserved for prosecutors the right to exercise such powers. See McNulty Memo, supra note 17, at 8-9. Most recently, the Department, in response to congressional inquiry, has again revisited its guidelines on seeking the waiver of the corporate privilege and suggested that, in response to continuing criticism, it would no longer seek such waiver as a condition of granting a DPA in the future. See Schmidt, supra note 17; see also Letter from Mark Filip, U.S. Deputy Att'y Gen., to Senator Patrick J. Leahy, Chairman, Comm. on Judiciary, and Senator Arlen Specter, Ranking Member, Comm. on Judiciary (July 9, 2008) [hereinafter Filip Letter], available at http://www.acc.com/resource/v9892 (follow "View this document" hyperlink). 
level of the individual employees within the corporation, or the knowledge, if any, that managers or directors had of those individuals' criminal conduct. Moreover, while factors such as the existence of an internal compliance program or the corporation's role in alerting authorities to the possibility of wrongdoing may be considered, they are not controlling, and a prosecutor remains free to charge - or threaten to charge-such corporations in pursuit of more far-reaching cooperation. ${ }^{184}$ The fact that prosecutors give little, if any weight, to those factors is puzzling if one views corporate criminal liability as an attempt to realistically assess a corporation's criminal wrongdoing. But it is not surprising at all in light of this Note's thesis that such criminal liability is less a reflection of principled criminal theory and more a tool of American prosecutors.

Perhaps most significant, however, is the fact that corporations are offered DPAs-and not traditional plea bargains-in the first place. Unlike plea bargains, which generally involve a reduction in the charges brought or a lighter sentence in return for a defendant's admission of guilt, a DPA is an agreement to dismiss an indictment entirely (or never seek one in the first place) in return for the defendant's cooperation. ${ }^{185}$ Offering a corporation a DPA, thus, is not merely offering leniency; it is a promise of absolution for any criminal liability, or as one critical account derisively termed it, a "get-out-ofjail-free card." ${ }^{86}$

\section{The American Outcome and Its Surprising Similarity to the German Outcome}

Operating under the terms of the Thompson Memo and its more recent successor, the McNulty Memo, federal prosecutors have had a great deal of success obtaining cooperation agreements from corporations and using those

Such recent changes do nothing to undercut the core contention of this Note-to the contrary, those changes, and the criticism that prompted them, strongly suggest the extent to which corporate criminal liability was a powerful tool developed and held by prosecutors. For a discussion of the McNulty Memo and some of the changes it ushered in, see, for example, Keith Paul Bishop, The McNulty Memo-Continuing the Disappointment, 10 CHAP. L. REV. 729 (2007).

184. See Thompson Memo, supra note 176 , at 8 ("[T] $]$ he existence of a compliance program is not sufficient, in and of itself, to justify not charging a corporation ...."); see also id. at 9 ("A corporate compliance program, even one specifically prohibiting the very conduct in question, does not absolve the corporation from criminal liability ....").

185. See Sklaire \& Berman, supra note 174 , at 1.

186. Lichtblau, supra note 172. 
agreements to pursue individual defendants. Consider just one recent and very high-profile example - the accounting firm KPMG. When informed that it was under investigation for tax fraud, KPMG quickly took significant steps in an effort to obtain a deferred prosecution agreement. KPMG thus agreed to waive the corporate privilege, to turn over the contents of its own internal investigation, and most controversially, to cut off the advancement of attorneys' fees to the individual partners under investigation, despite the fact that KPMG's partnership agreement explicitly required indemnification under the circumstances. ${ }^{187}$ As a result, KPMG was given a DPA and, to date, has never been charged with a crime. Prosecution of more than a dozen individual employees is ongoing. ${ }^{188}$

KPMG is hardly alone. Merrill Lynch cooperated fully, facilitating the prosecution of two bankers involved in the Enron scandal; ${ }^{189}$ AOL cooperated fully, leading four former executives to plead guilty to securities fraud; ${ }^{190}$ Adelphia entered into a DPA, helping to facilitate the prosecution of founder and former CEO John Rigas and his son, former CFO Timothy Rigas; ${ }^{191}$ WorldCom cooperated, leading to the successful prosecution of several former executives including former CEO Bernie Ebbers; ${ }^{192}$ and so on.

187. Cf. United States v. Stein, 435 F. Supp. 2d 330, 338-50, 381-82 (S.D.N.Y. 2006) (reviewing K.PMG's efforts to cooperate, and holding that its decision to cease indemnification in response to pressure from federal prosecutors violated the individual defendants' Fifth and Sixth Amendment rights). The Stein opinion, authored by Southern District of New York Judge Lewis A. Kaplan, has been the subject of a great deal of commentary-much of it laudatory as a matter of policy. Judge Kaplan's ruling was affirmed in its entirety by the Second Circuit in the summer of 2008. See United States v. Stein, No. 07-3042-CR, 2008 WL 3982104 (2d Cir. Aug. 28, 2008).

188. As a result of Judge Kaplan's decision in Stein that federal prosecutors had violated the constitutional rights of the individual defendants targeted, a number of those defendants moved for a dismissal of the indictment against them. Judge Kaplan granted that dismissal with regard to some, but not all of the defendants. See United States v. Stein, 495 F. Supp. $2 d 390$ (S.D.N.Y. 2007). That decision was also affirmed by the Second Circuit. See Stein, 2008 WL 3982104.

189. Letter from Leslie R. Caldwell, Dir., Dep't of Justice Enron Task Force, to Robert Morvillo and Charles Stillman, Counsel to Merrill, Lynch \& Co. (Sept. 17, 2003), available at http://www.corporatecrimereporter.com/documents/merill2003.pdf.

19o. Deferred Prosecution Agreement, United States v. America Online, Cr. No. 1:04 M 1133 (EDVA Dec. 15, 2004), available at http://www.corporatecrimereporter.com/ documents/aol.pdf.

191. Letter from David N. Kelley, U.S. Att'y for the S. Dist. of N.Y., to Alan Vinegrad and Philip C. Korologos, Att'ys for Adelphia Corp. (Apr. 25, 2005), available at http://www.corporatecrimereporter.com/documents/adelphia.pdf

192. By the time the agreement was reached, WorldCom had become MCI. Letter from David N. Kelley, U.S. Att'y for the S. Dist. of N.Y., to Charles P. Scheeler, Att'y for MCI Corp. (Aug. 
As a result, in the five years since the Enron fraud was first disclosed, just one corporation-Arthur Andersen-has been convicted of a crime at trial, while some 1100 individuals-including more than 200 CEOs-have pled guilty or been convicted of white-collar charges. ${ }^{193}$ Put differently, the result of so many of the recent investigations into corporate crime has generally been that the corporation itself is absolved of criminal liability. But the price it pays for such absolution involves the waiver of many evidentiary protections and assistance in the prosecution of individual employees.

With that general outcome in mind, perhaps surprisingly, the American system begins to look remarkably similar to the German system: corporations face no criminal liability - only individual employees do-but corporations also have no real power to block prosecutions of those individuals by, for example, invoking a wide-ranging attorney-client privilege to impede an investigation or assisting an individual defendant in retaining a team of high-priced attorneys to stave off indictment. Of course, in the United States, that result is achieved only through a negotiated deal that would neither be possible nor necessary in the German system. Put differently, the outcome mandated by German law is achieved in the United States only through negotiation, through the leveraging of prosecutorial powers on the one hand and defendants' rights and protections on the other.

Perhaps not surprisingly, that process of leveraging and negotiatingarguably more than the notion of corporate criminal liability itself-has prompted a great deal of criticism and anger on the part of corporations and their attorneys. ${ }^{194}$ But it is also quite instructive when understanding the explosion of the American doctrine. As one scholar noted, in the United States, " $\mathrm{t}]$ he mere threat of a criminal charge motivates firms to conduct in-house investigations, cooperate fully with prosecutors, distance themselves from the conduct of their agent, and jettison employees involved in the transaction."195 Translated more directly into the context of this discussion, the threat of corporate criminal liability prompts American corporations to forgo the unique procedural protections the American system affords them and to start acting much like a German corporation would be required to by German law under

30, 2005), available at http://www.corporatecrimereporter.com/documents/ mcinonpros_ooo.pdf.

193. Michael L. Seigel, Corporate America Fights Back: The Battle over Waiver of the Attorney-Client Privilege, 49 B.C. L. REV. 1, 3 (2008) (collecting data on these "staggering" numbers).

194. See, e.g., Diskant, supra note 2 (arguing that corporations "are at the mercy of prosecutors, whose demands ... must largely be obeyed" and concluding that this "creates an unhealthy imbalance in our system").

195. Moohr, supra note 3 , at 175 . 
similar circumstances. Additionally, as a result, the individual American employees at the core of any criminal investigation are placed in a similar position to their German counterparts - far less protected by the employers for whom they work and far more vulnerable to individual investigation and prosecution. And these realities-and what they mean for American prosecutors, corporations, and white-collar defendants - when extrapolated in a comparative context, are critical to understanding the development and explosion of entity liability in this country.

\section{CONCLUSION}

Writing on American corporate criminal liability, Gerhard Mueller rather famously noted, "nobody bred it, nobody cultivated it, nobody planted it. It just grew." 196 Mueller's quip, however clever, is neither unique in a field many scholars and practitioners have decried as unprincipled and under-theorized, ${ }^{197}$ nor, more important, is it entirely accurate. To the contrary, as this account would have it, the doctrine's somewhat unseemly growth may have been uncoordinated, but it was far from accidental, let alone inexplicable. American prosecutors, aided by an American Congress, American courts, and most important, an American system of criminal procedure, pushed, expanded, and manipulated the doctrine in the process of pursuing both corporations and individual employees to create the system we have today.

Indeed, the theoretical implications of this Note's central argument extend most directly to those critics who throw up their hands, decrying the lack of a centralized or theorized approach to the expansion of corporate criminal liability in the United States. The answer, as this Note has argued, is that there may be no overarching or logically satisfying theoretical explanation because the doctrine has expanded not solely as a legislatively driven policy choice, but instead, in significant part, as the result of individual, prosecutorial decisions in the context of specific cases. ${ }^{198}$

196. Gerhard O.W. Mueller, Mens Rea and the Corporation: A Study of the Model Penal Code Position on Corporate Criminal Liability, 19 U. PITT. L. ReV. 21, 21 (1957).

197. See supra notes $77-78$ and accompanying text (summarizing similar critiques).

198. This, of course, is not wholly to reject the relevance of the varying theoretical explanations addressed in Part $\mathrm{I}$. Each such theory undoubtedly offers some insight into the distinctions between the two systems. Differences in the theoretical view of the corporation, for example, play some role, as do different approaches to regulating corporate behavior and punishing criminal wrongdoing. Instead, the argument advanced here is meant to suggest that no explanation can be complete if it does not take into account the critical role that American 
For theorists seeking to explain when, and under what circumstances, American entity liability has expanded, the answers therefore are not likely to lie in policy or criminal theory. Instead, those critics should perhaps pay greater attention to when prosecutors would have felt the need to more aggressively pursue white-collar crime. Indeed, as this Note's thesis would have it, it is no mere coincidence that attempts to prosecute corporations first flourished the in the wake of the Industrial Revolution, that they blossomed anew in the mid-1980s in response to the market scams of the early Reagan Administration, and that they thrived in response to the rash of corporate fraud in the wake of the Enron collapse. At each relevant period, American prosecutors responded to waves of individual white-collar crime, and a critical component of that response was the decision to pressure the corporations those individuals worked for with the threat of entity liability.

Moreover, the fact that both the American and German systems ultimately pursue the same goal-the prosecution of individual wrongdoers-suggests that the account provided here may be more functionalist than initially anticipated. After all, the two systems pursue similar ends through distinct legal regimes developed in response to unique administrative and criminal justice systems. Appreciating the work functionalism could do here, however, requires a view of the "function" at stake as more than just the regulation of corporate behavior. Rather, it is the regulation of corporate behavior and individual white-collar criminals within the context of distinct criminal justice systems that allocate powers and protections very differently.

Leaving theory aside for a moment, the real value of the comparative work done here may be for practitioners and policymakers in the United States, many of whom are currently focused on reforming the American doctrine. As alluded to above, current American doctrine and prosecutorial practice have come under significant criticism from business leaders, the defense bar, and even politicians, all of whom generally decry the doctrine of corporate criminal liability. ${ }^{199}$ For such critics, the prevailing view of the doctrine as neither anchored to criminal theory nor logically developed policy has been a useful tool for attacking the current state of the law. ${ }^{200}$

By tying corporate criminal liability directly to the prosecution of individual wrongdoers, the account offered here sharply weakens those criticisms by placing the American doctrine in a broader context that both

criminal procedure has played in the development of the American doctrine of corporate criminal liability.

199. See supra notes $1-4$ (collecting examples of recent criticisms of the American doctrine levied by practitioners).

200. See id. 
explains its origins and justifies its significance. As this account would have it, if the doctrine of corporate criminal liability did not exist, American prosecutors would have considerably more difficulty pursuing individual wrongdoers, a goal even the most ardent critics of current practice would not and, indeed, could not find objectionable.

Perhaps more important, should reform of the American system occur, this Note provides a potential roadmap. Return, for a moment, to the conclusion reached above - that the German and American systems both pursue relatively similar ends, the jailing of individual wrongdoers rather than the corporations they work for, through vastly different procedures. In particular, while such a result is dictated by German law that would not permit charging a corporation in the first place, it is bargained for in the American system. Not surprisingly, it is within the context of that bargaining process that so many of the practices currently under attack in the United States arise: the ability of corporations to stymie investigations on the one hand, and the power of prosecutors to compel cooperation on the other.

Reforming the American practice and curbing these abuses could be achieved by borrowing from the German model, reducing the need for bargaining, and instead dictating the desired outcome by law. For example, Congress could curtail the corporate attorney-client privilege, giving prosecutors much greater access to information necessary to prosecute individuals, while at the same time eliminating large swaths of corporate criminal liability. Congress could also take more incremental steps, restoring the "control group" restriction on the scope of the corporate privilege, ${ }^{201}$ while at the same time limiting corporate criminal liability to those instances where the underlying conduct was committed or approved of by a controlling member of the corporation. ${ }^{202}$ The result of such reforms would be a system more in line with the German one, whereby corporations faced far less threat of criminal liability but also possessed fewer powers to protect guilty employees. $^{203}$

201. Prior to the Upjohn decision, see supra note 109, the "control group" test was law in the United States. Applying it, a court would ask whether the person speaking with corporate counsel was "in a position to control or even to take a substantial part in a decision about any action which the corporation may take upon the advice of the attorney." City of Phila.v. Westinghouse Elec. Corp., 210 F. Supp. 483, 485 (E.D. Pa. 1962).

202. With some exceptions, this is the position endorsed by the Model Penal Code. See MODEL PENAL CODE $\$ 2.07(1)$ (c) (1985).

203. Congress could similarly alter corporate behavior by enacting a "selective waiver" statute that preserved the corporate privilege in civil litigation even when corporations chose to waive it to cooperate with a criminal investigation, or Congress could require corporations to investigate and disclose any potential misconduct to federal prosecutors or make 
The crucial lesson the comparison to Germany offers, however, is that both American prosecutors and American corporations possess powers and privileges that their German counterparts do not possess-powers and privileges that can be, and arguably are, currently being abused. Reforming the American system, thus, while preserving the important and undisputed need to prosecute individual wrongdoers, ought to focus on reining in not just prosecutors, but corporations as well. Inherent in the very notion of bargaining, and certainly present in the American system, are carrots and sticks held by both sides. Curbing the powers of only one side might change that process, but it would do so by skewing the outcome, rather than by fixing the procedure by which the correct outcome was reached.

The above might seem like a rather straightforward, if not downright obvious, conclusion to draw, yet it is one currently lost in virtually all discussion of reforming the American system. Indeed, such discussion has focused almost exclusively on containing the powers prosecutors possess, with little or no attention paid to the corresponding rights and privileges corporations maintain. ${ }^{204}$ As just one blatant example of that phenomenon, consider again the crucial recent KPMG investigation. As noted above, in the wake of that investigation, critics assailed the allegedly abusive prosecutorial practice of forcing corporations to forgo indemnification of individual employees under investigation as a condition of obtaining a DPA. ${ }^{205}$ Virtually nothing, however, was made of the finding by a federal judge that KPMG had grossly overasserted, even abused, the corporate attorney-client privilege in an effort to stymie the investigation into those individual employees and the clients for whom they worked. ${ }^{206}$ As a result, the sole reforms to emerge from the KPMG case were voluntary decisions by the Department of Justice to change its practice with regard to indemnification and with regard to seeking

indemnification agreements illegal. For an interesting discussion of the potential for a selective-waiver doctrine, see, for example, Michael H. Dore, A Matter of Fairness: The Need for a New Look at Selective Waiver in SEC Investigations, 89 MARQ. L. REV. 761 (2006); and Andrew J. McNally, Comment, Revitalizing Selective Waiver: Encouraging Voluntary Disclosure of Corporate Wrongdoing by Restricting Third Party Access to Disclosed Materials, 35 SETON HALL L. ReV. 823 (2005).

204. See supra notes 194-195; see also supra note 180 (discussing recent, one-sided changes to the Thompson Memo that curb prosecutors without similarly disarming corporations).

205. See supra note 183 .

206. See United States v. KPMG LLP, 237 F. Supp. 2d 35, 48 (D.D.C. 2002) (Hogan, C.J.) (finding, after the government challenged KPMG's wide-reaching assertion of the corporate attorney-client privilege in response to a government subpoena, that less than fifteen percent of the documents for which the privilege was claimed were actually entitled to the protection of the privilege). 
waiver of the corporate privilege. ${ }^{207}$ In other words, the corporation's defense mechanisms like the privilege not only remained intact, but were given additional protection. ${ }^{208}$

Similarly, almost all of the proposed congressional reforms of the American doctrine have focused on limiting prosecutors - and prosecutors alone-from exercising many of the powers discussed above in the context of investigating and prosecuting corporate crime. For example, one prominent recent bill, the "Attorney Client Privilege Act of 2007," was aimed at protecting the corporate attorney-client privilege and would have precluded prosecutors from pressuring corporations to waive the privilege or even considering the issue of waiver in making charging decisions. ${ }^{209}$ Corporations would not have been disarmed in any comparable manner.

It is well beyond the scope of this Note to advocate for specific reform proposals or even to argue conclusively that reform of the American system is necessary. The goal, instead, is to advance a new way of thinking about the American doctrine, one grounded in a comparative approach that should be of use to policymakers, should they decide reform is prudent. And, for theorists and scholars who have long ignored the topic, the argument presented here is an invitation to revisit corporate criminal liability and its practical and theoretical significance through the prism of comparative law.

207. See supra note 17 .

208. If anything, the corporate attorney-client privilege was actually strengthened in the wake of the KPMG affair. The same McNulty Memorandum that modified Department of Justice guidelines on indemnification also significantly restricted federal prosecutors seeking waiver of the corporate privilege, requiring that any such request for a waiver be approved by Main Justice. See McNulty Memo, supra note 17, at 9-10. Most recently, the Department has suggested it will be even more hesitant to seek waiver of the privilege, restricting both the circumstances under which such a waiver will be sought and the nature of the information to be obtained should waiver be appropriate. See Filip Letter, supra note 183 .

209. See S. 186, 11oth Cong. (2007). The Senate never voted on this bill, though the House passed an identical version. See Elkan Abramowitz \& Barry A. Bohrer, Justice and Corporate Prosecutions: The Coming Saga, N.Y. L.J., Sept. 2, 2008, at 3. 